$$
=-
$$

NASA Technical Memorandum 103715

$$
\begin{array}{r}
N-20 \\
1619 \\
035
\end{array}
$$

\title{
Radiation Resistance of Thin- Film Solar Cells for Space Photovoltaic Power
}

(NASA-TM-103715) RAOIATION RESISTANCE OF THIN-FILM SOLAR CELLS FOR SPACE PHOTOVOLTAIC POWER (NASA) $35 \mathrm{P}$

CSCL 100

N91-19175

G3/20 $\begin{array}{ll}\text { Unclas } & 0001019\end{array}$

James R. Woodyard

Wayne State University

Detroit, Michigan

and

Geoffrey A. Landis

Lewis Research Center

Cleveland, Ohio

January 1991 
$=0=0$

a

$\equiv=-\cdots$

$\approx$

$+\cdots,-=$

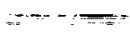

$-\cdots$

$\therefore=$

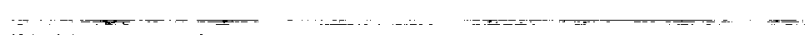




\title{
Radiation Resistance of Thin-Film Solar Cells for Space Photovoltaic Power
}

\author{
James R. Woodyard \\ Wayne State University, \\ Electrical and Computer Engineering Department, \\ Detroit, MI 48202. \\ Geoffrey A. Landis* \\ National Aeronautics and Space Administration \\ Lewis Research Center \\ Cleveland, $\mathrm{OH} 44135$.
}

\section{SUMMARY}

Copper indium diselenide, cadmium telluride and amorphous silicon alloy solar cells have achieved noteworthy performance and are currently being investigated for space power applications. Cadmium sulfide cells had been the subject of considerable effort but is no longer considered for space applications. This article presents a review of what is known about the radiation degradation of thin-film solar cells in space. Experimental investigations of the electron and proton degradation resistance of cadmium sulfide, copper indium diselenide, cadmium telluride and amorphous silicon alloy cells are reviewed. Damage mechanisms and radiation-induced defect generation and passivation in the amorphous silicon alloy cell are discussed in detail due to the greater amount of experimental data available.

\section{INTRODUCTION}

There is no universally accepted definition of a thin-film solar cell. In this paper we will refer to a thin-film solar cell as one made from thin amorphous and/or polycrystalline layers deposited on an inert substrate or superstrate. Thin-film solar cells are made from thin polycrystalline or amorphous semiconductor layers ranging from a fraction of a micron to a few microns in thickness. Various deposition technologies are used to fabricate cell structures on inert substrate or superstrate materials.

Typically, the materials used in the active layers of a thin-film solar cell are high optical absorption direct-bandgap semiconductors. Optical absorption coefficients greater than $10^{5} \mathrm{~cm}^{-1}$ result in a high level of light absorption. This allows the active layers in thin-film solar cells to be extremely thin, of the order of a few microns or less.

"NASA Lewis/NRC Resident Research Associate at NASA Lewis. 
Thin-film solar cells are currently the focus of research for low-cost terrestrial electricity production. Low materials usage, high throughput and automated deposition result in the potential for low production costs. Since large-area monolithicly-interconnected structures can be made, highly automated manufacturing system may be employed. Initial production efforts have focussed on amorphous silicon alloys; recently copper indium diselenide and cadmium telluride have exhibited desirable properties for low-cost large-area solar panels. Thin-film solar cells can also be made from a wide variety of other ternary and quaternary materials; few of these kinds of materials have been studied extensively.

One of the advantages of thin-film solar cells for space power applications is they have the potential for high specific power and stowability [1]. The specific power is the total power produced by an array divided by its mass; the mass includes the solar cell, substrate or superstrate, optical coatings, protective windows, encapsulants, grids, array supporting structures and connections to the power bus. Stowability, the power per unit volume, is a measure of the array storage volume needed to generate a required power level. The stowability will be larger for materials which are flexible and self supporting.

Thin-film solar cells can potentially have very low weight if the cells are deposited on low mass substrates or superstrates. However, most of the current technology development programs are directed at terrestrial use. The preferred substrate for terrestrial applications is typically about $1 / 4$ inch thick glass, which is inexpensive and rugged but not lightweight. Some consideration has been given to the use of light substrates for the fabrication of high specific power a-Si arrays for space power applications. Hanak and his collaborators $[2,3]$ showed that a-Si alloys can be made into flexible ultralight modules having thicknesses from 7.5 to 50 microns with thin metal or polyimide sheet substrates. Kishi and co-workers [4] fabricated amorphous silicon arrays on 20 micron thick plastic for a solar powered airplane. Others have also reported on the use of thin substrates with a-Si alloy solar cells; Wallace, Sabinsky. Stafford and Luft reported on the use of thin polyimide substrates [5]; Natakatani and co-workers of Teijin Ltd. studied cells on thin polyethylene terepthalate substrates [6]. However, for other cell materials, there is little or no research on alternative, lightweight substrates and superstrates. Additionally, little work has been done in the area of array design and encapsulation, and testing for space power applications.

Thin active layers result in higher radiation resistance; the reason suggested is that the number of electrically-active radiation-induced defects is related to the active layer thickness. This topic will be explored in more detall in the discussion on the radiation resistance of a-Si alloy solar cells.

Conversion efficiencies of thin-film solar cells are often quoted for terrestrial conditions, where the solar spectrum is filtered by passage through the terrestrial atmosphere. Efficiencies are usually reported for air mass 1 (AM1) and air mass 1.5 (AM1.5) spectra. Far fewer 
measurements have been made on cells under the extraterrestrial solar spectrum, referred to as AMO. Efficiency measured under an AMO spectrum is lower than under the AM1 or AM1.5 spectra because most of the additional light energy in the AMO spectrum is in the infrared and ultraviolet regions of the spectrum, where the spectral responce is very low.

A correction factor may be used to estimate an AMO efficiency from a measured AM1.5 efficiency. The exact correction factor will depend on the spectral response of the cell. Typically, a reduction in the AM1.5 efficiency of 15 to 20 percent is used for cells with bandgaps in the range of 1 to $1.5 \mathrm{eV}$. A multiplicative factor of 0.8 has been reported to correct an a-Si alloy cell from an AM1.5 to an AMO efficiency [3].

Thin-film photovoltaic materials developed for terrestrial use which may be adapted to space power arrays include $\mathrm{CuInSe}_{2}$ and a-Si alloys [1]. These applications include solar electric propulsion, a manned Mars mission, and lunar exploration and manufacturing. While the efficiencies are low compared to space cells based upon crystalline materials, the projected specific power levels are still extremely good. Additionally, the development of multi-bandgap thin-film tandem structures has shown that efficiencies can be improved significantly.

While thin-film technologies have not yet developed a record of performance in space, there is a large manufacturing base which has been developed for terrestrial applications: tens of megawatts per year for a-Si alloys, a rapidly increasing capability for CuInSe $e_{2}$, and a moderately small capability of perhaps tens of kilowatts per year for CdTe. By contrast, U.S. space solar cell requirements have been nearly constant at 100-120 kW per year for nearly a decade.

Overall, for space power applications, thin-film solar cells have potential advantages of:

-high specific power

-large area solar cells with integral series interconnections

-flexible blankets

-large body of array manufacturing experience

-potential low cost

-potential high radiation tolerance

with the corresponding potential disadvantages of:

-lower efficiency

-lack of spacecraft experience

-lack of current production with space qualified encapsulants and lightweight superstrates and/or substrates. 


\section{TYPES OF THIN-FIIM SOLAR CELLS}

\subsection{CdS/ $\mathrm{Cu}_{2} \mathrm{~S}$ Thin-Fulm Solar Cells.}

The first thin-film solar cell developed was the heterojunction cadmium sulfide/copper sulfide cell. In earlier references the cell was often referred to as the "CdS" cell; the role played by the $\mathrm{Cu}_{2} \mathrm{~S}$ layer was obscure. The best efficiency was about $8 \%$ AMO [7], and the cells had excellent radiation resistance $[8,9,10]$. There was some difficulty in achieving good stability against humidity. These cells were made obsolete by the development of more stable and higher efficiency thin-film materials.

\subsection{CuInSe, Thin-Film Solar Cells}

A thin-film photovoltaic material of great interest and currently under investigation is copper indium diselenide $\left(\mathrm{CuInSe}_{2}\right)$ and copper indium diselenide/copper gallium diselenide alloys [11]. Several fabrication technologies have produced AMO efficiencies of over $10 \%$ [12]; the technologies for deposition of the cell layers onto substrates and superstrates include vacuum evaporation, reactive sputtering, and electroplating. In general, cell processing involves deposition temperatures and/or annealing temperatures of about $450^{\circ} \mathrm{C}$. The high processing temperature is a problem for space applications where it would be desirable to deposit the cell onto a thin polyimide material such as Kapton. Deposition onto a thin substrate or superstrate has not yet been demonstrated.

The bandgap of CuInSe $\mathrm{e}_{2}$ is about $1.0 \mathrm{eV}$ and the optical absorption coefficient is greater than $10^{5} \mathrm{~cm}^{-1}$ above the band edge. Existing cells consist of a layer of the active copper indium diselenide, typically about 3 microns in thickness; a front contact and heterojunction window of either cadmium/zinc sulfide or zinc oxide plus cadmium sulfide, with a thickness of about one micron; and a back contact of molybdenum. A CuInSe $_{2}$ cell efficiency of $13 \%$ AM1.5 has been reported by Mitchell, Eberspacher, Ermer and Pier [13]; the corresponding AMO efficiency is $10.4 \%$ using a factor of 0.8 for conversion from AM1.5. Efficiencies of $12 \%$ AMO are expected to be achievable in the near term.

Other I-III-VI 2 semiconductors have also been studied for solar cell use. An AM1 efficiency of $10.2 \%$ has been reported for a CuIn $\mathrm{In}_{1-\mathrm{x}} \mathrm{Ga}_{\mathrm{x}} \mathrm{Se}_{2}$ cell [14]; while the efficiency is lower than $\mathrm{CuInSe}_{2}$, it offers future promise. Other materials of interest include $\mathrm{CuGaSe}_{2}$ and $\mathrm{CuInS}_{2}$. No radiation testing has been done on these materials to date. 


\subsection{CdTe Thin-Film Solar Cells}

Another high-absorption coefficient material suitable for thin-film deposition is cadmium telluride (CdTe). The bandgap of CdTe is $1.44 \mathrm{eV}$, very close to the optimum value for the AMO spectrum. Thin-film CdTe solar cells have been produced in thin-film form by a wide variety of deposition methods, including vacuum evaporation, close-space sublimation, electrodeposition, and screen printing [15]. Processing temperatures of about $450^{\circ} \mathrm{C}$ are typical. Recently thin-film CdTe cells have been made which resulted in corrected AMO efficiencies as high as 9.8\% [16]. Like CuInSe $e_{2}$, it is currently not produced on thin substrates or superstrates. Unlike CuInSe $\mathrm{C}_{2}$, most CdTe deposition methods produce a cell on a superstrate: the cell is deposited inverted upon a glass sheet, which then serves as a front cover.

\section{4 a-Si Alloy Cells}

The most intensively researched thin-film solar cell material, and the material with the largest body of array manufacturing experience, is amorphous silicon (a-Si) alloy. The material commonly referred to as a-Si is an alloy containing silicon and other elements. Examples of a-Si alloys are: silicon and hydrogen, a-Si:H; silicon, hydrogen and fluorine, a-Si:H,F; silicon, germanium and hydrogen, a-Si,Ge:H; silicon, germanium, hydrogen and fluorine, a-Si,Ge:H,F; and silicon, carbon and hydrogen, a-Si,C:H. The hydrogen incorporation is necessary for good electronic properties and can range from a few percent to as much as $15 \%$. An amorphous Si alloy thin film differs from the other solar cell materials in that its structure is amorphous rather than crystalline.

While several deposition methods have been used in the fabrication of a-Si alloy devices, plasma enhanced chemical vapor deposition (PECVD) is commonly used in large scale fabrication. The method consists of flowing gases, such as silane at a few Torr pressure, through a chamber in which there a plasma discharge is sustained by radio-frequency power. Silicon complexes and hydrogen deposit on a heated substrate maintained at about $250^{\circ} \mathrm{C}$. Doped $\mathrm{n}$ and $\mathrm{p}$ layers are produced by adding gases such as phosphine and diborane to the gas-flow stream.

The optical bandgap of device grade a-Si:H ranges between 1.7 and $1.8 \mathrm{eV}$, which is a reasonable match to the solar spectrum. The bandgap can be tailored further by addition of carbon to raise the bandgap or of germanium to reduce it. Most testing is done at simulated AM1.5; two published simulated AMO measurements on single junction a-Si alloy based cells report efficiencies of $4.85 \%$ [17] and $8.57 \%$ [18]. Cell efficiencies have been improved with multi-bandgap multi-junction structures, as well as bandgap profiling within a junction. a-Si,Ge:H,F alloys, along with bandgap profiling, have been used by Guha, Yang, Pawlikiewicz, Glatfelter, Ross and Ovshinsky to fabricate a triple tandem 
structure with a $0.25 \mathrm{~cm}^{2}$ area to achieve a $13.7 \%$ AM 1.5 efficiency [19].

A difficulty experienced with amorphous silicon is light-induced degradation, known as the Staebler-Wronski effect [20]. First generation a-Si modules experienced between 20 and $40 \%$ degradation upon exposure to light [21]. Yang, Ross, Mohr and Fourler found that the performance of a triple cell with an initial efficiency of $11.2 \%$ degraded about $15 \%$ [22]. Sabinsky and Stone reported on recent tests of cells from three manufacturers; they concluded that "...multi-junction cells show reductions in efficiency of only around $10 \%$ for cells with initial efficiencies as high as 11\%" [21]. It is believed that future improvements in materials and cell design, as well as a better understanding of the physics of light-induced degradation, will reduce the degradation still further.

Amorphous Si alloy solar cells for terrestrial use are the subject of very large and active research programs, currently funded at several million dollars per year. Much of this research will likely be applicable to space.

\section{RADIATION RESISTANCE OF THIN-FILM SOLAR CELLS}

The data on radiation damage to thin-film cells is a large but unorganized data set covering a wide range of cell types, fluences, energies and test conditions including irradiations with both protons and electrons. It must be kept in mind that results obtained by researchers at one institution are not necessarily directly comparable to data on cells of nominally the same material fabricated at another institution. In general, the details of cell structure and efficiency are different for different investigations; they also change with time as improved cell materials and designs supplant older ones in the quest for higher cell efficiencies and improved stabilities. It should also be cautioned that the older radiation resistance results may not apply to future cells, since the improved structures and materials may have a major influence on radiation resistance. For example, recent a-Si solar cells are designed to reduce degradation due to Staebler-Wronski effect; however, many of the design and materials changes developed to minimize this effect are also likely to reduce radiation damage effects.

For this reason, radiation damage values on cells alone are of only partial value. It is also important to understand the mechanisms of radiation damage, in order to be able to understand and predict the effect of cell design changes on radiation tolerance.

This section will discuss the radiation resistance of completed solar cells. Since considerable work has been done on the mechanisms of radiation damage to amorphous silicon films, a separate section, section 4, will discuss these studies. The reason for discussing damage mechanisms in a-Si alloy based materials at length is that a-Si is the only material which has been the subject of fundamental studies of the radiation effects on the opto-electronic properties. 


\subsection{Electron Irradiation Resistance of $\mathrm{CdS} / \mathrm{Cu}_{2} \mathrm{~S}$ Cells.}

While $\mathrm{CdS} / \mathrm{Cu}_{2} \mathrm{~S}$ cells are no longer considered a potential candidate for photovoltaic power generation, considerable work was done between 1963 and 1968 to characterize the effects of radiation. The results are still of some interest because they are qualitatively representative of the effects of radiation on other types of thin-film cells. In general, thin-film $\mathrm{CdS} / \mathrm{Cu}_{2} \mathrm{~S}$ solar cells have shown excellent radiation tolerance, with no degradation in power for $1 \mathrm{MeV}$ electron fluences up to $10^{16} \mathrm{~cm}^{-2}$. This led to the hope that thin-film cells in general would have high radiation resistances, an expectation which has for the most part been met.

The first electron irradiation studies of $\mathrm{CdS} / \mathrm{Cu}_{2} \mathrm{~S}$ cells were reported by Schaefer in 1963 [23]. The initial efficiencies were about 2\% and the cells had Mylar covers which were about 25 microns thick. A degradation of about $10 \%$ in the initial efficiencies was observed when the cells were irradiated with $1 \mathrm{MeV}$ electron fluences of about $10^{15}$ $\mathrm{cm}^{-2}$. The degradation was later interpreted as being caused by the darkening of the Mylar covers [24].

Brandhorst and Hart reported electron irradiation results in 1964 on $\mathrm{CdS} / \mathrm{Cu}_{2} \mathrm{~S}$ cells [25]. The cells were encapsulated in various plastic films of unspecified thicknesses. Ten cells were irradiated in air using 0.60 , 1.00 and $2.50 \mathrm{MeV}$ electrons with fluences ranging between $10^{15}$ and $10^{17} \mathrm{~cm}^{-2}$. The cells were mounted on a water-cooled plate; temperatures during irradiation did not exceed $60^{\circ} \mathrm{C}$. The initial cell efficiencies were about $2 \%$ and the areas $2 \mathrm{~cm}^{2}$. The short-circuit current, open-circuit voltage, power, spectral response, series resistance and shunt resistance were investigated. The cells, encapsulated in Mylar and " $\mathrm{H}$ film" [Kapton] showed no degradation at any of the energies and fluences up to $10^{16} \mathrm{~cm}^{-2}$. At $4 \cdot 10^{16} \mathrm{~cm}^{-2}$ and higher fluences, all 21 cells showed efficiency degradations of 50 to $90 \%$ when they were tested immediately following irradiation. The degradation was primarily in the short-circuit current. The spectral response measurements showed the greatest decrease in carrier collection occurred in the blue region of the spectrum. The initial efficiencies were restored when the cells were placed in open-circuit conditions and exposed to various light levels; light levels of $40 \mathrm{~mW} / \mathrm{cm}^{2}$ for 24 hours and "ambient room light for several days" restored the efficiencies. No annealing was observed under short-circuit or maximum-power conditions.

Bernard, Berry, Buisson, and Paillous investigated electron irradiation of $\mathrm{CdS} / \mathrm{Cu}_{2} \mathrm{~S}$ cells and Acklar covers in vacuum and argon [26]. The radiation resistance of the covers was investigated both with and without bonding adhesive. The electron beam energy was $600 \mathrm{keV}$ prior to entering the sample chamber. In order for the beam to enter the chamber, it traversed two aluminum windows of 50 micron thicknesses. The authors estimated the irradiating electron beam energy at the surface of the cell was about $450 \mathrm{keV}$. An electron fluence of $1.7 \cdot 10^{16}$ 
$\mathrm{cm}^{-2}$ produced degradation in the cell spectral response primarily in the blue region of the spectrum. The electron irradiation did not degrade the Aklar covers but the bonding adhesive apparently degraded and absorbed light primarily in the blue region of the spectrum; the adhesive degradation accounted for most if not all the cell degradation.

\subsection{Proton Irradiation Resistance of $\mathrm{CdS} / \mathrm{Cu}_{2} \mathrm{~S}$ Cells.}

Schaefer and Statler tested the effect of $1.8 \mathrm{MeV}$ and $3 \mathrm{MeV}$ protons on CdS/ $\mathrm{Cu}_{2} \mathrm{~S}$ cells. The cells had efficiencies of about $2 \%$ and 25 micron thick Mylar covers [24]. At a maximum fluence of $4.10^{12} \mathrm{~cm}^{-2}$, the efficiencies degraded about 2 and $4 \%$ for 1.8 and $3.0 \mathrm{MeV}$ protons, respectively; the degradations were due to decreases in the short-circuit current. Some of this effect may be due to cover darkening.

Brandhorst and Hart irradiated $\mathrm{CdS} / \mathrm{Cu}_{2} \mathrm{~S}$ cells with 2.0, 5.0, 7.0 and $10 \mathrm{MeV}$ protons with fluences ranging between $10^{12}$ and $4 \cdot 10^{14} \mathrm{~cm}^{-2}$. The investigations were carried out under the same conditions as discussed above for the electron irradiation studies [25]. The post-irradiation maximum powers were $80 \%$ to $90 \%$ of the initial powers with fluences of $4 \cdot 10^{14} \mathrm{~cm}^{-2}$; the degradations were not strongly dependent on the proton irradiation energies. They attributed the degradation to loss of short circuit current and to increased series resistance.

Degradation studies of unencapsulated $\mathrm{CdS} / \mathrm{Cu}_{2} \mathrm{~S}$ cells were carried out by Hui using low energy protons [27]. The effect of a protective Mylar window was also investigated. Cells with $11 \mathrm{~cm}^{2}$ areas and roughly $5 \%$ efficiencies were irradiated with proton energies of 50,100, and 400 $\mathrm{keV}$ and fluences ranging between $10^{12}$ and $5 \cdot 10^{14} \mathrm{~cm}^{-2}$. Degradations of about $20 \%$ were reported in both the open-circuit voltage and short-circuit current at fluences of $5 \cdot 10^{14} \mathrm{~cm}^{-2}$. There was a slight dependence on the irradiating proton energy; degradations in the open-circuit voltage and short-circuit current were slightly larger at 100 $\mathrm{keV}$. No improvement was observed in the radiation resistance of cells constructed with 25 micron thick Mylar covers. However, a cover of silicone with an unspecified thickness resulted in no degradation of cells exposed to $400 \mathrm{keV}$ proton fluences up to about $10^{14} \mathrm{~cm}^{-2}$.

Curtin investigated proton irradiation of $\mathrm{CdS} / \mathrm{Cu}_{2} \mathrm{~S}$ cells with 25 micron Kapton covers [28]. Cells were $2 \mathrm{~cm}^{2}$ in area and had efficiencies of $3.6 \%$; they were irradiated in four cell groups with proton energies of $0.60,0.80,1.00,1.20,1.40,2.00,4.00$ and $5.00 \mathrm{MeV}$. For proton energies less than $1.40 \mathrm{MeV}$, no open-circuit voltage degradation was observed suggesting the proton energy was too low to penetrate the Kapton cover; degradation in the short-circuit was observed and shown to be due to the degradation in the optical transmission of the Kapton cover. The change in the optical properties of Kapton was verified by measurements of the optical transmission as a function of proton 
irradiation. Protons with energies greater than $1.40 \mathrm{MeV}$ were expected to penetrate the Kapton. At these energies, the power output of the cells degraded negligibly at a fluence of $10^{13} \mathrm{~cm}^{-2}$; they degraded to about $90 \%$ of the initial power at a fluence of $10^{14} \mathrm{~cm}^{-2}$. Degradations in the initial power of $45 \%$ and $70 \%$ were observed at a fluence of $10^{15} \mathrm{~cm}^{-2}$, with the worst degradation being at $2.0 \mathrm{MeV}$ and the least degradation at $5.0 \mathrm{MeV}$; significant open-circuit voltage degradation was seen only for 1.6 and $2.0 \mathrm{MeV}$ protons.

In summary, both the electron and proton radiation resistance of the $\mathrm{CdS} / \mathrm{Cu}_{2} \mathrm{~S}$ thin-film cells were superior to that of single-crystal cells. Even though the initial efficiencies were low, the post-irradiation efficiencies for high fluences exceeded the crystalline cells. This result encouraged the development of thin-film solar cells using other materials.

\subsection{Electron and Proton Irradiation Resistance of $\mathrm{CuInSe} e_{2}$ Cells.}

The first experiments on electron irradiations of $\mathrm{CuInSe}_{2}$ were reported in 1984 by Gay, Potter, Tanner and Anspaugh [17]. They studied cells with areas of $0.18 \mathrm{~cm}^{2}$ and AMO efficiencies of $7.37 \%$ The cells were irradiated with $1 \mathrm{MeV}$ electrons with fluences ranging between $10^{14}$ and $10^{16} \mathrm{~cm}^{-2}$. The irradiations produced no changes greater than the experimental accuracy (estimated at about 5\%) in the open-circuit voltage, fill factor or short-circuit current.

Studies of the electron and proton radiation resistance of CuInSe $\mathrm{C}_{2}$ cells were reported by Dursch, Chen and D. Russell in 1985 [29]. They report irradiation of the cells with $1 \mathrm{MeV}$ electrons to fluences up to $2 \cdot 10^{16} \mathrm{~cm}^{-2}$ with no loss of efficiency. Protons with $1 \mathrm{MeV}$ energies were used to irradiate cells to six fluences ranging from $2.5 \cdot 10^{10}$ to $5 \cdot 10^{13} \mathrm{~cm}^{-2}$. Eleven cells with $1 \mathrm{~cm}^{2}$ areas and $A M 1$ efficiencies ranging between 7.7 and $9.6 \%$ were investigated. The cells had aluminum gridded front contacts, a two micron thick In-doped CdS window, 3 to 4 microns of $\mathrm{CuInSe}_{2}$, a two micron molybdenum back contact, and an alumina substrate. The degradation in the performance (averaged over all eleven cells) due to the proton irradiations is shown in Fig. 1. The degradation is negligible for fluences up to $10^{11} \mathrm{~cm}^{-2}$. Above this fluence it decreases to $40 \%$ of the initial value at a fluence of $5 \cdot 10^{13} \mathrm{~cm}^{-2}$. Most of the degradation was in the open-circuit voltage and fill factor; negligible degradation was measured in the short-circuit current and the spectral response except at very high fluence. Figure 2 shows the effect of the irradiation on the I-V curve. The authors suggested that the irradiation damage occurs near the junction of the cell. The relative cell efficiency recovered to $95 \%$ of the Initial value with a six minute anneal at $225^{\circ} \mathrm{C}$. They compared the $1 \mathrm{MeV}$ proton irradiation resistance of the $\mathrm{CuInSe}_{2}$ cell to crystalline GaAs and Si. The CuInSe 2 cell shows about 50 times more radiation resistance to $1 \mathrm{MeV}$ proton radiation than either $\mathrm{Si}$ or GaAs.

It remains to be seen whether the high radiation resistance will be a 
property of future high-performance versions of the CuInSe 2 cell technology. However, the radiation resistance of existing cells is sufficiently high that the end of life (EOL) efficiency of even present-day cells may be higher than that of conventional crystalline cell technologies in high-radiation space environments.

\subsection{Electron Irradiation Resistance Of CdTe Cells.}

The electron radiation resistance of thin-film CdTe cells have been reported by Bernard and co-workers using the same techniques discussed above in their work on CuInSe ${ }_{2}$ [26]. Cells were irradiated both bare and protected by Krylon, a spray-on polymer film. The cells were irradiated with approximately $450 \mathrm{keV}$ electrons and the degradation was the same for the bare and Krylon-coated films. The cells were highly resistant to the electron irradiation; only a small decrease in the short-circuit current was measured at a fluence of $3 \cdot 10^{16} \mathrm{~cm}^{-2}$. The spectral response decreased slightly at short wavelengths and increased insignificantly at long wavelengths.

\subsection{High-energy Electron Irradiation Resistance of a-Si.Cells.}

The first study of high energy particle irradiation effects on a-Si:H solar cells was reported in 1983 by Katayma, Morimoto and Sugawara [30]. They irradiated single-junction a-Si:H,F alloy gridded ITO $/ n^{+}{ }^{i p}{ }^{+}$ structures fabricated on stainless steel, with area of about $1 \mathrm{~cm}^{2}$. The cell cross-sectional structure is show in Fig. 3 . The cells were produced by PECVD using silane as the source gas for the intrinsic layer. The transparent conductor was an indium tin oxide (ITO) layer about $100 \mathrm{~nm}$ thick. Phosphine and diborane were used for doping the $\mathrm{n}^{+}$and $\mathrm{p}^{+}$ layers, of thicknesses $X_{n}=15 \mathrm{~nm}$ and $X_{p}=70 \mathrm{~nm}$, respectively. Intrinsic layers with thicknesses of $X_{i}=200,500$ and $700 \mathrm{~nm}$ were investigated. The cell was deposited on a flexible stainless steel substrate $0.2 \mathrm{~mm}$ in thickness.

AM1 cell efficiencies were between five and seven percent. The degradation rate, as indicated by the change in the relative power efficiency, was independent of the initial efficiency. Electrons with an energy of $1 \mathrm{MeV}$ and fluences of $10^{13}$ to $10^{16} \mathrm{~cm}^{-2}$ were used to irradiate solar cells. Fig. 4 shows the variation in relative efficiency versus thickness and fluence. There is no noticeable degradation for a fluence of $10^{13} \mathrm{~cm}^{-2}$ for the three thickness. A fluence of $10^{14} \mathrm{~cm}^{-2}$ produces no noticeable degradation in cells with $200 \mathrm{~nm}$ thick intrinsic layers; the 500 and $700 \mathrm{~nm}$ thick cells show degradations of a few percent and $20 \%$, respectively. Fluences of $10^{15}$ and $10^{16} \mathrm{~cm}^{-2}$ produce significant reductions in the relative cell efficiencies which decrease with increasing intrinsic layer thickness. The relative efficiency is less than about $20 \%$ at a fluence of $10^{16} \mathrm{~cm}^{-2}$ for all intrinsic layer thicknesses. Fig. 5 shows the quantum efficiency of a cell with an intrinsic layer thickness of $500 \mathrm{~nm}$. The spectral response shows significant changes at a fluence of $10^{14}$ $\mathrm{cm}^{-2}$; it decreases and the peak shifts to higher wavelengths with 
increasing fluences. The authors reported that the initial efficiencies recovered with annealing in air at $200^{\circ} \mathrm{C}$ for one hour. Dark current-voltage characteristics before irradiation and as a function of fluence showed the reverse saturation current increased and the slope tended to decrease with increasing fluences. The detailed current-voltage characteristics were not reported and it is not possible to determine the role the open-circuit voltage, short-circuit current and fill factor play in the reduction of the relative power efficiency. It was suggested that atomic displacements and the introduction of dangling bonds in the intrinsic layer reduce the minority carrier drift lengths. However, no analyses was presented to support the suggestions.

Studies of the effect of $1 \mathrm{MeV}$ electrons on single junction a-Si:H cells were conducted by Gay, Potter, Tanner and Anspaugh [17]. They irradiated pin cells with $1 \mathrm{MeV}$ electron fluences of $10^{14}, 10^{15}$ and $10^{16}$ $\mathrm{cm}^{-2}$. The structures of the cells were $\mathrm{Al}(200 \mathrm{~nm}) / \mathrm{p}^{+} \mathrm{in}^{+} / \mathrm{tin}$ oxide/quartz substrate; the AMO efficiencies were about $8.5 \%$. The thicknesses of the layers were not specified. The cells were 1rradiated through the Al film and showed an average efficiency degradation of 39\% at a fluence of $10^{16} \mathrm{~cm}^{-2}$; most of the degradation was in the fill-factor with only a $7 \%$ change in the open-circuit voltage and $4 \%$ ' in the short-circuit current. The spectral irradiance degraded by about $10 \%$ in the ultraviolet and 5\% in the red regions of the spectrum. An air anneal at $175^{\circ} \mathrm{C}$ for fifteen minutes restored over $97 \%$ of the initial cell efficiency. The authors did not speculate on the mechanisms involved in defect production and annealing. The relative insensitivity of the spectral irradiance to the irradiation, as compared to the measurements of Katayma, Morimoto and Sugawara [30], may be due to the cell structure; the $\mathrm{p}^{+}$layer of the cells of Gay et al. is near the surface, resulting in a higher collection efficiency for holes generated near the surface. This point is discussed at greater length later in the section on basic damage mechanisms in a-Si alloy solar cells.

Byvik, Slemp, Smith and Buoncristiani also studied the effect of electron irradiation on single junction a-Si:H solar cells with initial AMO efficiencies of about 5\% [18]. They used $1 \mathrm{MeV}$ electrons with fluences between $10^{14}$ and $10^{16} \mathrm{~cm}^{-2}$ and irradiated grid/ITO/n+ip ${ }^{+} /$stainless steel structures; the cell layer thicknesses were not specified. The current-voltage characteristics of a typical cell with irradiation is show in Fig. 6. The figure shows that the open-circuit voltage is somewhat insensitive to the fluence while the fill factor decreases for fluences above $10^{14} \mathrm{~cm}^{-2}$. The short-circuit current decreases significantly for a fluence of $10^{16} \mathrm{~cm}^{-2}$. Typically, irradiation of the cells resulted in efficiency degradations of $7.4,25$ and $99.8 \%$ with fluences of $10^{14}, 10^{15}$ and $10^{16} \mathrm{~cm}^{-2}$; a fluence of $10^{16} \mathrm{~cm}^{-2}$ produced a decrease of $67 \%$ in the short circuit current, $28 \%$ in the fill factor and $9.9 \%$ in the open circuit voltage. The normalized spectral response of irradiated cells decreased by about $80 \%$ at $440 \mathrm{~nm}$ with the decrease less as the wavelength increased to $600 \mathrm{~nm}$; beyond $600 \mathrm{~nm}$ the irradiation had a negligible effect on the cell response. 
Annealing the damaged cells for two hours at $200^{\circ} \mathrm{C}$ in vacuum restored the open circuit voltage; the short circuit current, fill factor and efficiency were restored to $91 \%, 95 \%$ and $85 \%$, respectively, of the initial values. An increase in the surface recombination rate for excess charge carriers resulting from surface damage was suggested as the mechanism for the reduction in carrier collection efficiency. It was suggested that the defect annealing mechanism was that proposed by Street, Biegelsen and Stuke [31], discussed in section 4.1, namely, the passivation of mid-gap recombination centers by the hydrogenation of dangling bonds.

\subsection{Low-energy Electron Irradiation Resistance of a-Si Cells.}

The effect of $20 \mathrm{keV}$ electron irradiation on a-Si alloy cells has been reported by Schneider and Schröder [32]. Cells of conversion efficiency $\sim 7 \%$ were irradiated in a scanning electron microscope with fluences in the range of $10^{14}$ to $10^{17} \mathrm{~cm}^{-2}$ under conditions where the beam-induced annealing was believed to be unimportant. The cell structure was glass $/ \mathrm{p}^{+}(\mathrm{SiC}: \mathrm{H}) / \mathrm{i}(\mathrm{Si}: \mathrm{H}) / \mathrm{n}^{+}(\mathrm{Si}: \mathrm{H}) / \mathrm{Al}$. The cell layer thicknesses were not specified. Reductions of the order of a few percent in the relative open-circuit voltage, short-circuit current and fill factor, and of the order of $10 \%$ in cell conversion efficiency, were opserved at a fluence of $10^{14} \mathrm{~cm}^{-2}$; at a fluence of $10^{17} \mathrm{~cm}^{-2}$, the corresponding decreases are $50 \%, 70 \%, 55 \%$ and $92 \%$, as shown in fig. 7 . Significant room temperature annealing was observed. The efficiency was restored to $90 \%$ of the initial value with annealing at $130{ }^{\circ} \mathrm{C}$ for six hours. The authors attribute the degradation as caused by the same defects as Staebler-Wronski light-Induced degradation. It is notable that this work reports degradation of a-Si solar cells by $20 \mathrm{keV}$ electrons is greater than that of $1 \mathrm{MeV}$ electrons with the same fluence [17].

\subsection{Proton Irradiation Resistance of a-Si Cells.}

The first studies of proton radiation resistance on a-Si alloy cells were reported concurrently by Schwarz, Kolodzey, Aljishi, Wagner and Kouzes [33] and by Hanak, Myatt, Nath and Woodyard [34].

Schwarz et al. studied the effects of $12 \mathrm{MeV}$ protons on a-Si:H Schottky barrier cells using proton fluences ranging from $9 \cdot 10^{12}$ to $7.3 \cdot 10^{15} \mathrm{~cm}^{-2}$. Film thicknesses were between 0.7 and 2.0 microns and deposited on 8 micron thick Al substrates by PECVD. The top contacts were $\mathrm{Pd}$ or $\mathrm{Cr}$ semi-transparent dots two millimeters in diameter. Protons with energies of $12 \mathrm{MeV}$ deposit energy uniformly in a-Si:H films by nuclear and electronic stopping; they have ranges of about one millimeter and therefore readily passed through the Schottky barrier cells. The investigators found that as the fluence increased from $9 \cdot 10^{12}$ to $7.10^{15} \mathrm{~cm}^{-2}$, the normalized short-circuit current decreased sublinearly from 1.0 to about 0.01 and the open-circuit voltage decreased from $230 \mathrm{mV}$ to $70 \mathrm{mV}$. An initial defect density of $1.7 \cdot 10^{16} \mathrm{~cm}^{-3} \mathrm{eV}^{-1}$ was used for the cells in the analysis of the results. The initial spectral 
response of the short-circuit current peaked at about $600 \mathrm{~nm}$; following irradiation it was attenuated by about a factor of ten at $400 \mathrm{~nm}$ and decreased monotonically as the wavelength increased. The irradiation also increased the sub-gap optical absorption and decreased the minority carrier diffusion length from about 0.18 to 0.02 microns.

Annealing studies showed partial recovery of the normalized short-circuit current, but the results were complicated by the deterioration of the metal contacts during the anneals. Following irradiation of the cells, measurements of the normalized short-circuit current showed a few percent increase over a time interval of about five minutes. The effect was interpreted as evidence of room temperature annealing.

The authors developed a model to explain the sublinear decrease in the normalized short-circuit current with increasing fluence. They assumed the normalized short-circuit current was inversely proportional to the radiation induced defect density; the radiation induced defect density was related to the proton fluence raised to some power; the model produced a reasonable fit to the data. In considering the defect generation mechanism, the authors' analysis of the transport properties result in an estimate of an average of 0.03 defects produced per proton per micron; 0.019 defects per proton per micron are estimated from an analysis using the cross section for nuclear displacements by the protons and the number of knock-ons producing displacements. Considerations of defects produced by the electronic stopping of the protons did not lead to an estimate of defect densities because of the lack of data on the relationship between irradiating beam current density and defect densities. It is concluded that the inherent disorder in a-Si:H and the presence of hydrogen makes it difficult to identify the defect generation mechanism. Also, the authors generalize and state that it is wrong to conclude a-Si:H is more radiation resistant than $\mathrm{c}-\mathrm{Si}$; they conclude that the high initial defect density of a-Si:H makes it appear to be more radiation resistant than $\mathrm{c}-\mathrm{Si}$. The conclusion is drawn from a materials perspective and does not consider the importance of device design in determining radiation resistance. The investigations were carried out with Schottky barrier structures which are thick, have low conversion efficiencies and operate by diffusive carrier transport. The work shows the importance of the solar cell structure and the initial characteristics of device materials in determining the radiation resistance of thin film a-Si alloy based solar cells.

The proton radiation resistance studies of a-Si: $\mathrm{H}$ alloy based solar cells reported by Hanak, Myatt, Nath and Woodyard included measurements on both single and tandem junction cells [34]. They reported the results of irradiating sixty a-Si alloy thin film solar cells with $1.0 \mathrm{MeV}$ protons ranging in fluences from $10^{11}$ to $10^{15} \mathrm{~cm}^{-2}$. The structures are the same as shown in Fig. 3 except the $p^{+}$layer is next to the ITO layer and the $\mathrm{n}^{+}$layer next to the stainless steel substrate. The films were deposited by PECVD and the intrinsic layer thicknesses were between about 250 and $500 \mathrm{~nm}$. Three types of cells were studied. Two types were single-junction cells with different kinds of alloys in the 
intrinsic layers. The alloys were a-Si:H,F and a-Si,Ge:H,F with bandgaps of 1.7 and $1.5 \mathrm{eV}$, respectively. The single-junction cells had grid/ITO/ $\mathrm{p}^{+} \mathrm{in}^{+} /$stainless steel structures. The third type of cell which was studied had a tandem cell structure of grid/ITO $/ \mathrm{p}^{+} \mathrm{in}^{+} / \mathrm{p}^{+} \mathrm{in}+/$ stainless steel and the two junctions were same-gap a-Si:H,F alloys. The conversion efficiencies were between 6.0 and $8.5 \%$ for all the cells. The irradiations were through the 60 nanometer thick ITO films.

Fig. 8 shows the variation of the relative conversion efficiency with $1.00 \mathrm{MeV}$ proton fluence. Figure 9 shows the open-circuit voltage, short-circuit current, fill-factor and conversion efficiency at $10^{14} \mathrm{~cm}^{-2}$. The conversion efficiency decreases approximately logarithmically with dose starting from about one at $10^{12} \mathrm{~cm}^{-2}$ and decreasing to about zero at $10^{15} \mathrm{~cm}^{-2}$. Fig. 9 shows that for a fluence of $10^{14} \mathrm{~cm}^{-2}$, most of the decrease in the relative efficiency is due to changes in the fill factor and short-circuit current; the open-circuit voltage changed less than about $10 \%$. Both Figs. 8 and 9 show that the single-junction cells degrade slightly more than the tandem-junction cells for the same fluence. The intrinsic layers in the single-junction cells are thicker than the intrinsic layers in the tandem-junction cells. The observation of poorer radiation resistance for thicker cells is consistent with the observations of both Kalayama et al. [30] and Schwarz et al. [33]. The annealing data shown in Fig. 8 were measured after annealing the cells at $160^{\circ} \mathrm{C}$ for the times specified. A one-hour anneal eliminates the defects produced by $1 \mathrm{MeV}$ protons with fluences less than about $10^{14} \mathrm{~cm}^{-2}$; with a fluence of $10^{15}$ $\mathrm{cm}^{-2}$, annealing for twenty-six hours restores a tandem cell to the initial relative efficiency.

Hanak, Fulton, Myatt, Nath and Woodyard irradiated and annealed single-gap tandem cells with $200 \mathrm{keV}$ protons, and compared the results with the degradation and annealing of cells irradiated with $1.00 \mathrm{MeV}$ protons [35]. They used the same cells and techniques reported in the earlier work of Hanak et al. [34]. The results of the work are shown in Fig. 10. The $200 \mathrm{keV}$ protons produced more degradation in the relative conversion efficiency than the $1.00 \mathrm{MeV}$ protons. Protons at $200 \mathrm{keV}$ and a given fluence produced about the same degradation as $1.00 \mathrm{MeV}$ protons with fluences about five to ten times greater. The annealing studies showed the conversion efficiencies could be restored, but the damage introduced by the $200 \mathrm{keV}$ protons was more resistant to annealing than the damage produced by $1.00 \mathrm{MeV}$ protons.

Hanak, Chen, Fulton, Myatt and Woodyard then studied thirty dual-gap tandem cells under $200 \mathrm{keV}$ and $1.00 \mathrm{MeV}$ irradiation in order to determine the relative radiation resistance of dual-gap tandem solar cells as compared with single-gap tandem cells and single junction cells [2]. They also attempted to understand the defect-generation mechanisms by comparing the energy dependence of the cross sections for nuclear and electronic stopping of protons in the a-Si:H alloys. The tandem cells had grid/ITO/ $\mathrm{p}^{+} \mathrm{in}^{+} / \mathrm{p}^{+} \mathrm{in}^{+} /$stainless steel structures. The intrinsic layer nearest the surface was fabricated with an a-Si:H,F alloy; the bottom intrinsic layer was fabricated with an a-Si,Ge:H,F alloy. The 
conversion efficiencies of the thirty tandem cells were between 9.37 and $11.48 \%$; the mean was $10.44 \%$. Fig. 11 shows the effect of $200 \mathrm{keV}$ and $1.00 \mathrm{MeV}$ on the AMl conversion efficiencies. The $200 \mathrm{keV}$ protons have about the same effect on the decrease of efficiency as $1.00 \mathrm{MeV}$ protons at about five times the fluence. A comparison of these data with Fig. 10 shows the fluence dependence of the degradation of the dual-gap tandem cells is about the same as the single-gap tandem cells. The effect of the Irradiation on the open-circuit voltage, short-circuit current and fill factor was similar to Fig. 9, with the open-circuit voltage relatively insensitive to $1.00 \mathrm{MeV}$ protons for fluences less than $10^{15} \mathrm{~cm}^{-2}$.

Annealing studies showed that the efficiencies recovered in a manner similar to the single-gap tandem cells illustrated in Fig. 8.

The investigators compared the radiation resistance of the dual-gap tandem cells with other cells. Fig. 12 shows the effect of $1.00 \mathrm{MeV}$ proton irradiation on the relative efficiency of crystalline Si [36], GaAs [36], CuInSe ${ }_{2}$ [29] and a-Si alloy dual-gap tandem cells. Also shown in the comparison is the effect of $10 \mathrm{MeV}$ protons on single-crystal InP cells [37]; the $10 \mathrm{MeV}$ data are shown for comparative purposes because of the lack of $1.00 \mathrm{MeV}$ proton radiation resistance data for InP cells. While a-Si alloy dual-gap-tandem cells have a proton degradation resistance which is only slightly better than CuInSe 2 and InP cells, it is about 50 to 100 times more radiation resistant than crystalline Si and GaAs.

Abdulaziz, Payson, Li, and Woodyard [38] compared the $1.00 \mathrm{MeV}$ proton radiation resistance of a-Si:H cells with that of a-Si,Ge:H cells with germanium concentrations in the range of approximately $20-30 \%$. The study looked at fluences of $10^{14}$ to $10^{15} \mathrm{~cm}^{-2}$. The material incorporating germanium material degraded slightly more than the a-Si:H alone; efficiency decreased to $22 \%$ of initial power at $10^{14} \mathrm{~cm}^{-2}$ for the a-Si,Ge:H cell compared to $39 \%$ of initial efficiency for the material with no germanium incorporation. They also compared single junction a-Si:H cells to single-gap, dual-junction a-Si:H cells, concluded that at high fluences, the radiation induced degradation of the dual junction cells could not be explained simply as the sum of two non-interacting single-junction cells.

\subsection{Space Flight Experience on Thin Film Cells}

To date only one experiment with thin-film cells has been flown in space. Both a-Si and CuInSe ${ }_{2}$ cells are now flying on the solar cell experiment on the LIPS-III satellite. This was launched in spring 1987 into a $1100 \mathrm{Km}$ orbit of 60 degrees inclination [39]. There is some difficulty in analysing the experiment due to noise in the data and temperature stability problems, however, some useful information can be drawn from the data.

a-Si alloy cells from ECD/Sovonics and from Solarex were flown on LIPS-III. The ECD/Sovonics cells used a EVA/Tedlar encapsulant. This choice of an encapsulant was unfortunate, since EVA is subject to 
darkening under exposure to ultraviolet. The encapsulant darkening in this case was severe enough that no useful data was received about the cell performance. Two Solarex a-Si cells were flown. Both were fabricated on ceria-doped glass of roughly 300 microns thickness, which served as the cell coverglass.

Three CuInSe $\mathrm{C}_{2}$ cell strings manufactured by Boeing were flown. One was uncovered, one had a CMX coverglass of approximately 250 micron thickness affixed with DC 93-500 adhesive, and the third was flown with a GaAs wafer used as a filter, as well as a CMX coverglass and adhesive. Data are being collected via telemetry. The cumulative radiation exposure is not yet high enough to draw many conclusions from results published to date. Data after the first year in orbit is reported in reference [40]. It is encouraging to note that, from the $I_{s c}$ data, no degradation is measured in the CuInSe $\mathrm{C}_{2}$ cells after three years exposure in space; in fact, the performance of the uncovered $\mathrm{CuInSe}_{2}$ cell has, if anything, improved slightly.

\section{Radiation Effects on a-Si Alloy Thin-Film Materials}

An understanding of radiation damage mechanisms is important both as an aid to understanding cell test data, to the extrapolation of radiation test results to other cell designs and radiation energies, and to assist cell design studies to minimize radiation damage.

The ideas introduced by the investigators who studied thin films are important in developing an understanding of the defect generation and passivation mechanisms in solar cells fabricated from a-Si alloys. The literature dealing with a-Si alloys is unique because thin-film and solar cell studies, and more generally device studies, have had a symbiotic relationship since their beginnings; the relationship has been nurtured by investigators because the development of photovoltaic technology is critically dependent on an understanding of the materials. We will emphasize the effect of radiation on opto-electronic properties in the effort to develop an understanding of both the defect generation and annealing mechanisms.

\subsection{Irradiation Studies of a-Si Alloy Thin-Film Materials.}

Among the first studies reported in the literature is the work by Engemann, Fischer, Richter and Wagner, who irradiated a-Si: $\mathrm{H}$ thin films with a variety of ions and monitored photoluminescence [41]. They used photoluminescence to determine the effects of annealing and to characterize the defect states. $1.00 \mathrm{MeV}$ protons, $100 \mathrm{keV}$ helium and $400 \mathrm{keV}$ oxygen with fluences of about $10^{16} \mathrm{~cm}^{-2}$ were used to irradiate glow discharge deposited a-Si:H films with thickness less than the range

of the lons. Irradiation reduced the luminescence intensity by a factor of a thousand, which was the limit of detectability. Their work showed that annealing at temperatures of 220 to $300^{\circ} \mathrm{C}$ restored the luminescence 
intensity almost, but not completely, to the value before irradiation. The details of the temperature dependence of annealing differed for the various ions, and the bombarding hydrogen and oxygen appeared to play a role in defect passivation. Proton and oxygen bombarded films annealed easier than inert ion-bombarded films, suggesting that the implanted hydrogen and oxygen chemically passivated defects. The authors interpreted the ion bombardment-induced reduction in photoluminescence as due to the introduction of electronic energy states in the sub-bandgap region; it was suggested that the sub-bandgap states acted as centers for both radiative and non-radiative recombination. The suggestion of bombardment induced centers for non-radiative recombination was based on work which was subsequently published [42] and showed that ion bombardment resulted in an increase in spin densities and a decrease in the luminescence intensity. They also suggested that bombardment introduced a broad distribution of electron traps about $0.15 \mathrm{eV}$ below the conduction band edge and a broad distribution of hole traps about $0.35 \mathrm{eV}$ above the valence band edge; the postulated trap densities made it possible to explain the luminescence spectra of bombarded and annealed films.

Voget-Grote, Stuke and Wagner reported on fon bombardment of glow discharge deposited a-Si:H thin films [42]. a-Si:H films were bombarded with $100 \mathrm{keV}$ helium ions to introduce defects to determine the effect of the defects on electron spin resonance signals (ESR). The fluence was not reported, however, the fact that the spin densities were in the range of $10^{19}$ to $10^{20} \mathrm{~cm}^{-3}$ suggests that the fluence was probably at least $10^{16} \mathrm{~cm}^{-2}$. Samples were also prepared by evaporation with different substrate temperatures, and subsequently annealed, to vary the density of unpaired spins. Ion bombardment and variations in deposition and annealing conditions were used to produce samples with spin densities in the range of $10^{18}$ to $10^{20} \mathrm{~cm}^{-3}$. The electrical conduction mechanism was believed to be due to carrier hopping for these large spin densities. The main relaxation mechanism for the observed large spin signals was the spin-lattice interaction where a hopping electron interacts with another electron spin within avoid. The work showed that the ESR signals were not uniquely related to the spin density. Materials bombarded and prepared in different ways to produce the same spin densities, had vastly different ESR saturation powers, linewidths and hopping conductivities. The investigations suggested that several different defect structures exist in a-Si:H thin films, and that the type and density of the defect structures depend on the history of the material. While this observation is still valid, it is important to note that recent work [43] shows the radiation resistance of solar cells is sensitive to defect densities of the order of $10^{15}$ to $10^{17} \mathrm{~cm}^{-3}$, or five orders of magnitude lower than the highest defect densities used by Voget-Grote et al.

High energy radiation resistance studies of glow-discharge deposited a-Si:H films were carried out by Street, Biegelsen and Stuke [31]. Luminescence and ESR were used to characterize the defects introduced by $\mathrm{He}^{+}$and $\mathrm{e}^{-}$bombardment of a-Si:H films of thicknesses 0.2 to 100 microns deposited on glass. $\mathrm{He}^{+}$irradiations were carried out at 100 
$\mathrm{keV}$ with fluences of $10^{16} \mathrm{~cm}^{-2}$, and electron irradiations at $1.0 \mathrm{MeV}$ with fluences of $10^{19} \mathrm{~cm}^{-2}$. The irradiations quenched the luminescence and increased the spin densities. Helium produced a greater quenching of the luminescence and a larger increase in spin densities; these effects were associated with radiation-induced defects. The increased defect generation for helium irradiation, as compared to electron irradiation, was associated with the larger collisional kinematic factor for helium. The authors carried out an analysis of the collisional energy deposition and spin densities in order to determine the effect of ambient annealing; they concluded that the majority of broken bonds reconstruct.

The defects produced by both helium and electrons could be removed by annealing at temperatures up to $300^{\circ} \mathrm{C}$. Annealing from room temperature to $300^{\circ} \mathrm{C}$ resulted in a partial recovery of the luminescence intensity and a reduction in the spin density. However, the full initial luminescence intensity was not restored. For annealing above $300^{\circ} \mathrm{C}$, the spin density increased, suggesting a temperature-induced degradation of the films. The temperature-induced degradation was believed to be due to hydrogen evolution and the creation of silicon dangling bonds. The details of the annealing of the luminescence intensity and spin density depended on the method of preparation of the thin films and the type of bombarding particle. This suggested the importance of the structure and composition of the films in defect annealing; it also pointed to the difference in the defect structures produced by different bombarding particles. The fact that the ESR signal of the bombarded films first decreased with annealing to $250^{\circ} \mathrm{C}$, and then increased to become relatively stable at $600^{\circ} \mathrm{C}$, led the authors to suggest that the motion of hydrogen was involved in the defect annealing.

A $0.9 \mathrm{eV}$ luminescence peak was observed with spin densities in the range of $2 \cdot 10^{16}$ to $2 \cdot 10^{17} \mathrm{~cm}^{-2}$; the peak was attributed to recombination involving either a trapped electron and a self-trapped hole in the valence band tail or a self-trapped electron in the conduction band tail and a trapped hole. In either case the trap was about $0.3 \mathrm{eV}$ from the respective band edge. The band edge luminescence peak energy increased from about 1.0 to $1.4 \mathrm{eV}$ with increased annealing temperatures. The effect was explained assuming broadening of the band tails originating from the damage introduced by bombardment. It was suggested that radiation introduces defects with unpaired spins which serve as recombination sites for non-radiative recombination; the unpaired spin results from a dangling bond due to an unsaturated silicon bond. During annealing the dangling bonds may coalesce to form spinless centers for non-radiative recombination. The authors indicated that it was unclear if the dangling bonds were produced by radiation induced-displacement of hydrogen or by the displacement of silicon followed by diffusion, reconstruction and the formation of voids with dangling bonds.

The ideas presented by Street et al. have been adopted by several authors to explain observations. However, one must note that the quality of a-Si:H films has improved significantly since this work. Additionally, the large electron fluences and the use of relatively low energy helium 
ions produced major structural changes in the films. The major structural changes make it difficult to determine the fundamental effects of high energy particle irradiation on a-Si:H alloyed based films.

It is noteworthy that low energy electron irradiation has been observed to influence the properties of a-Si films [32]. Schade [44] reported a fluence of $10^{18} \mathrm{~cm}^{-2} 5-\mathrm{keV}$ electrons degraded the photoluminescence and the annealing behavior was complex; he suggested temperature-assisted rearrangement of irradiation-affected bonds in order to explain the annealing of the relative photoluminescence. More recently, Schneider and Schröder [45], and Schneider, Schröder and Finger [46] used a scanning electron microscope to irradiate a-Si films with $20 \mathrm{keV}$ electron fluences in the range of about $10^{15}$ to $10^{17} \mathrm{~cm}^{-2}$; they concluded the defects produced by $20 \mathrm{keV}$ electrons are identical to defects produced by light exposure.

\subsection{Defect Generation and Passivation Mechanisms in a-Si alloy Cells.}

Some of the mechanisms which could lead to the decrease of the conversion efficiency of a-Si alloy based cells due to proton irradiation were investigated $[2,47,48]$. Fig. 11 shows that $200 \mathrm{keV}$ protons of a given fluence have about the same effect on the relative efficiency as 1 $\mathrm{MeV}$ protons with about five times the fluence. The relative efficiency curves of the $1 \mathrm{MeV}$ proton irradiations, when shifted to the left by a factor of five in fluence, compare favorably with the $200 \mathrm{keV}$ data except for the highest fluences. The factor of five increase in degradation for $200 \mathrm{keV}$ protons, as compared with the $1 \mathrm{MeV}$ protons, is used to evaluate the primary defect-generation mechanism.

In order to determine if electronic or nuclear collisions is the primary defect generation mechanism, the stopping powers are considered. As Table 1 shows, the small values of the stopping powers result in the protons losing about $10 \%$ of their energy in layers about 100 $\mathrm{nm}$ thick. Only a small fraction of the proton energy is deposited in the cells and the protons come to rest in the substrates. Therefore, the collision rate is uniform with respect to depth; the defect-generation rate is also expected to be uniform.

Table 1: Proton/Si Nuclear and Electronic Stopping Powers

$\begin{array}{ccc}\text { Proton Energy } & \begin{array}{c}\text { Nuclear Stopping } \\ \text { Power } \\ (\mathrm{keV} / \mathrm{micron})\end{array} & \begin{array}{c}\text { Electronic Stopping } \\ \text { Power } \\ (\mathrm{keV} / \mathrm{micron})\end{array}\end{array}$

$200 \mathrm{keV}$

0.101

119

$1.00 \mathrm{MeV}$

0.022

44 
The ratio of the nuclear stopping powers at $200 \mathrm{keV}$ and $1 \mathrm{MeV}$ is 4.5, while the ratio of the electronic stopping powers is 2.7 . The stopping power calculations, and the fact that the $200 \mathrm{keV}$ protons degrade the cell efficiency five times more than the $1-\mathrm{MeV}$ protons, suggest that nuclear knock-on collisions are important in generating the defects. The role of the defects produced by the displacement of the primary knock-on can be considered by calculating the total cross sections for primary knock-on collisions. The total cross sections are calculated for the collision of protons with hydrogen, $\mathrm{Si}$ and $\mathrm{Ge}$ using a simplified Rutherford model assuming $3.5 \mathrm{eV}$ for the hydrogen displacement energy, and $13 \mathrm{eV}$ for $\mathrm{Si}$ and Ge. As Table 2 shows, the total displacement cross sections are about five times larger at $200 \mathrm{keV}$ than $1 \mathrm{MeV}$.

Table 2. Proton/Si Total Cross Sections and Number of Displacements.

$\begin{array}{lrcc}\text { System } & \begin{array}{c}\text { Energy } \\ (\mathrm{keV})\end{array} & \begin{array}{c}\text { Cross Section } \\ \left(\mathrm{cm}^{-2}\right)\end{array} & \text { Displacements } \\ \mathrm{H} \rightarrow \mathrm{H} & 200 & 9.3 \mathrm{E}-20 & 5.6 \\ \mathrm{H} \rightarrow \mathrm{H} & 1000 & 1.9 \mathrm{E}-20 & 6.4 \\ \mathrm{H} \rightarrow \mathrm{Si} & 200 & 1.8 \mathrm{E}-19 & 4.0 \\ \mathrm{H} \rightarrow \mathrm{Si} & 1000 & 3.4 \mathrm{E}-20 & 4.8\end{array}$

The $\mathrm{H} \rightarrow \mathrm{Si}$ total cross section is about two times greater than the $\mathrm{H} \rightarrow \mathrm{H}$ cross section. Since the relative hydrogen atomic density is about $10 \%$ for the a-Si:H alloy cells, it was suggested that the relative number of $\mathrm{Si}$ and Ge primary knock-ons is at least twenty times greater than the number of hydrogen primary knock-ons [47]. The total number of atomic displacements per proton includes the primary knock-on displacements and the displacements produced by the recoiling primary knock-ons. The number of secondary displacements can be calculated using the Kichin and Pease model [49]. The results of the calculations are shown in Table 2; the total number of displacements per primary knock-on is about five for protons in the $200 \mathrm{keV}$ to $1 \mathrm{MeV}$ energy range, irrespective of whether the primary knock-on is hydrogen, Si or Ge.

The analysis suggests the reduction in the relative conversion efficiency of the cells is due to defects produced by proton knock-on collisions with $\mathrm{Si}$ and $\mathrm{Ge}$. Within the modelling constraints the calculated defect densities are about $4 \cdot 10^{16} \mathrm{~cm}^{-3}$ at a $200 \mathrm{keV}$ proton fluence of $10^{12} \mathrm{~cm}^{-2}$. It is generally agreed that high quality a-Si alloy cells have an intrinsic defect density of about $10^{15}$ to $10^{16} \mathrm{~cm}^{-3}$, which produces energy states in the bandgap [50]. Irradiation-induced defect 
densities of the order of the intrinsic defect densities would be expected to degrade the performance of a cell. Fig. 11 shows that the degradation in the relative efficiency of the dual-gap tandem cells is discernable at a fluence of $10^{12} \mathrm{~cm}^{-2}$; the above calculations predict a defect density of about $4 \cdot 10^{16} \mathrm{~cm}^{-3}$ for defects produced by nuclear displacement of Si or Ge by $200 \mathrm{keV}$ protons with a fluence of $10^{12} \mathrm{~cm}^{-2}$. If the Irradiating protons produce defects which result in energy states in the bandgap on a one-for-one basis, then it would be expected a radiation induced defect density of about $10^{15}$ to $10^{16} \mathrm{~cm}^{-3}$ would produce a discernable reduction in the relative efficiency. Hence, the calculated defect density is about five to ten times higher than expected. This finding suggests that either there is annealing of the defects during or following the irradiation, that all the defects are not electrically active, and/or that the model is in error. The prediction of a higher defect density for crystalline $\mathrm{Si}$ has also been reported; the observation of a lower electrically-active defect density is believed to be caused by the annealing of the displacement damage within 100 seconds of the irradiation [51].

The open-circuit voltage of a-Si alloy based cells is relatively insensitive to the proton fluence for fluences less than about $10^{15} \mathrm{~cm}^{-2}$; most of the degradation is in the short-circuit current and in the fill factor [2,35]. This observation and the annealing behavior of the conversion efficiency at low temperatures suggests that the defects are produced primarily in the intrinsic region of the cell and that the $\mathrm{p}^{+}$and $\mathrm{n}^{+}$layers are not degraded by the bombarding protons. Certainly, if the collision cascades produced by the energetic protons intermixed the $\mathrm{p}^{+}$ and $\mathrm{n}^{+}$layers with the intrinsic layer, low temperature anneaking would not be expected to restore the layers and their electrical behavior. Since the $\mathrm{p}^{+}$and $\mathrm{n}^{+}$layers are much thinner than the intrinsic layer, most of the primary knock-ons and defects will be produced in the intrinsic layer. Further confirmation that the doped layer are essentially unaltered by the irradiation and that the defects are introduced in the intrinsic layer is evidenced by the relative effect of the protons on cells with different thicknesses. Fig. 10 shows that the single junction a-Si:H:F cells, which have thicker intrinsic layers than both the single junction a-Si:Ge:H:F cells and the single-gap tandem cells, degrade more at a given proton energy and fluence.

Street et al. [31] suggested protons displace atoms and create dangling bonds which are passivated by the diffusion of hydrogen upon annealing. Hydrogen, $\mathrm{Si}$ and $\mathrm{Ge}$ are the main possibilities for knock-on displacements in a-Si alloys. If the displacement of hydrogen were the sole defect mechanism, Woodyard and Hanak [47] suggested that the defects would anneal by the migration of hydrogen; annealing data should behave in an Arrhenius fashion with a single activation energy corresponding to hydrogen diffusion. They analyzed their relative efficlency data and were unable to find convincing evidence for single activation energy which could be associated with the diffusion of hydrogen. It was concluded that the passivation of the electrically active defects produced by proton irradiation was more complex than a mechanism involving the diffusion of hydrogen in the film. 
The dependence of a-Si alloy material quality on radiation resistance and room temperature annealing effects have recently been reported by Payson, Abdulaziz, Li and Woodyard [52]. The investigators found that solar cells fabricated in 1989 showed superior radiation tolerance to 1 $\mathrm{MeV}$ protons when compared to cells fabricated in 1985. While prior radiation history and cell structure were different for the cells, the work suggested that the material properties may be responsible for improved radiation resistance.

Systematic experiments were carried out to monitor the current-voltage characteristics of cells immediately following irradiation and subsequently as a function of time. The objective was to determine whether a room temperature annealing effect existed in solar cells fabricated from a-Si alloys. The investigators observed room-temperature annealing for both the 1985 and 1989 sets of solar cells. The 1989 cells annealed at a faster rate than the 1985 cells for the same $1 \mathrm{MeV}$ proton fluence.

From this annealing work it was apparent that there are at least two types of defects; one type annealed significantly at room temperature and the another annealed only after one-hour anneal at $200^{\circ} \mathrm{C}$. They reported that some devices had improved characteristics following Irradiation and annealing. Improvements were seen in the current-voltage characteristics of solar cells following irradiation and annealing. The investigators also reported an improvement in a thin film property following irradiation and annealing; a reduction in the sub-bandgap optical absorption of thin films was observed using photothermal deflection spectroscopy (PDS). A film irradiated with 1.00 $\mathrm{MeV}$ proton to a fluence of $1.67 \cdot 10^{15} \mathrm{~cm}^{-2}$ had a significantly lower sub-bandgap optical absorption following an anneal for one hour at $185^{\circ} \mathrm{C}$ [53]. The results, in addition to suggesting that improved materials appear to increase the radiation resistance of solar cells, raise fundamental questions about radiation-induced mechanisms which also improve the quality of both cells and films.

Quantitative predictions of the behavior of these solar cells in the space environment will require knowledge of the degradation and annealing mechanisms. Future experiments should be directed at separating these two competing mechanisms, along with determining the microscopic mechanisms causing degradation and annealing in hydrogenated amorphous silicon alloy solar cells.

The recent observation of the room-temperature annealing effect ralses questions about the interpretations of the earlier proton irradiation experiments [52]. The existence of room-temperature annealing makes it difficult to determine both the defect generation and passivation mechanisms. It is likely that attempts to quantify the defects introduced by proton irradiation were not successful because of the role of annealing [35]. If room temperature annealing removes defects which are different from the defects which anneal at temperatures in the 160 to $200^{\circ} \mathrm{C}$ range, the results reported in the literature characterize only the defects which anneal at the higher temperatures. It may be that the defects which anneal at room temperature are produced by the electronic 
stopping of $\mathrm{MeV}$ protons, while the defects which anneal at higher temperatures are produced by nuclear stopping. Additional experiments are necessary in order to elucidate the basic defect production and annealing mechanisms for the defects introduced by high-energy proton irradiation.

The 1-MeV electron irradiation results of Katayama et al. [30] can be analyzed to elucidate the fundamental aspects of radiation resistance of a-Si:H films and solar cells. The reduction in cell efficiency with electron fluence is a clear indication of the decrease in carrier collection efficiency. This is also confirmed by Fig. 4 which shows the decrease of the collection efficiency for $1-\mathrm{MeV}$ fluences above $10^{14} \mathrm{~cm}^{-2}$ when the intrinsic layer is $500 \mathrm{~nm}$. The mechanism suggested by Katayma et al. [30], namely the reduction of the minority carrier diffusion length, is not consistent with the current understanding of carrier transport in a-Si:H solar cells. The carrier transport in a-Si:H solar cells is primarily due to carrier drift in the intrinsic layer. This can be shown by a simple analysis which considers the electric field and carrier injection in the intrinsic layer. The approximate value of the electric field can be estimated using the intrinsic layer thickness and the open-circuit voltage. The current-voltage characteristics of a single junction a-Si:H solar cell with an intrinsic layer thickness of about $250 \mathrm{~nm}$ is shown in Fig. 13; the open-circuit voltage is about $0.86 \mathrm{~V}$. The average electric field in the solar cell is of the order of $30,000 \mathrm{~V} / \mathrm{cm}$. The optical absorption coefficient for device grade a-Si:H is shown in Fig. 14. The figure shows that the optical absorption coefficient is less than $10^{6} \mathrm{~cm}^{-1}$ for the spectral region shown; this results in the absorption of light over distances greater than $10 \mathrm{~nm}$ for all the wavelengths considered. This value of the optical absorption length results in negligible diffusive carrier transport when compared to drift transport. Hence, it follows that carrier transport in a-S:H solar cells occurs primarily by carrier drift.

The role of the absorption length in the carrier collection efficiency can be seen by reference to Fig. 5 . Note that the spectral response of the before-irradiation solar cell first increases as the wavelength increases from about 400 to $550 \mathrm{~nm}$; it then decreases as the wavelength increases. The initial increase in spectral response with increasing wavelength, for this particular cell structure, can be correlated, at least in part, with the increase in the absorption length with wavelength as shown in Fig. 14. This statement assumes that contacts, and window and $n^{+}$layers do not dominate the short-wavelength optical absorption at the front of the cell. Illumination with a wavelength of $400 \mathrm{~nm}$ produces electron-hole pairs near the front of the cell because the absorption length is about $40 \mathrm{~nm}$. Since the cell structure, as shown in Fig. 3, is grid/ITO $/ n^{+}-1-p^{+} /$stainless steel, the electric field is directed from the $n^{+}$layer to the $\mathrm{p}^{+}$layer. The electrons injected near the front of the cell are readily collected at the ITO $/ \mathrm{n}^{+}$contact. In order for holes injected near the front of the cell to be collected, they must drift through the $i$ and $p^{+}$layers before being collected at the $\mathrm{p}^{+} /$stainless steel contact. Fig. 5 shows that the collection efficiency for holes injected at $400 \mathrm{~nm}$ is small, however, as the wavelength of the light is increased, the hole collection efficiency increases. The increase in hole collection efficiency with increasing 
wavelength is due to the injection of holes deeper in the intrinsic layer; holes injected deeper in the intrinsic layer are collected with higher probabilities because they have shorter distances to drift to the $\mathrm{p}^{+} /$stainless contact for collection.

Above $550 \mathrm{~nm}$, increasing the wavelength results in a decrease in the collection efficiency. This decrease is due to the increase in the absorption length with increasing wavelength. As the absorption length increases and becomes larger than the thickness of the intrinsic layer, the number of electron-hole pairs injected in the cell decreases. The decrease in injected carrier density results in the collection of fewer carriers, and a decrease in the spectral response of the cell. For wavelengths greater than $700 \mathrm{~nm}$, the absorption length is greater than $500 \mathrm{~nm}$ and only an insignificant fraction of the light injects carriers in the solar cell. The room temperature hole drift mobility in a-Si:H is about 100 to 1000 times smaller than the electron drift mobility [54]. The collection efficiency for holes injected near the front of the cell can be increased by collecting the holes at the front contact of the cell. This may be accomplished using a structure with a front contact $/ \mathrm{p}^{+}$in ${ }^{+} / \mathrm{back}$ contact structure resulting in the electric field directed from the back contact to the front contact; the field direction for this structure is opposite to the field direction for the structure shown in Fig. 3. Amorphous Si alloy based solar cells are currently fabricated with a front contact $/ \mathrm{n}^{+} \mathrm{ip} \mathrm{p}^{+} /$back contact structure in order to take advantage of the larger electron drift mobility.

The defect generation mechanisms for the stopping of electrons in a-Si:H involve atomic displacements and electronic excitation. The role of atomic displacements in the electron irradiation work $[17,18,30]$ can be estimated using the Darwin-Rutherford model for the displacements of atoms by the $1 \mathrm{MeV}$ electrons [55]. The calculated density of $\mathrm{Si}$ primary knock-ons varies linearly with fluence and is about $10^{16} \mathrm{~cm}^{-3}$ at a fluence of $10^{16} \mathrm{~cm}^{-2}$; the $\mathrm{H}$ primary knock-on density is about an order of magnitude less. The role of primary knock-ons in producing secondary atomic displacements may be estimated using the Kinchin-Pease theory [49]; the calculations show that each primary knock-on produces of the order of one secondary displacement. Analysis of the displacement damage density must include defect reducion by ambient annealing and radiation-induced annealing effects. Analysis must also include the effect of multiple electrically active defects produced per displacement. Assuming of the order of one electrically active defect per atomic displacement, it is expected that a density of $10^{16}$ electrically active defects per $\mathrm{cm}^{3}$ represents a reasonable upper limit at an electron fluence of $10^{16} \mathrm{~cm}^{-3}$. This defect density must be compared with the intrinsic defect density of a-Si:H thin films in order to determine the effect of electron irradiation on the reduction of the relative solar cell efficiency. It is generally accepted that the intrinsic defect density in device quality a-Si:H is about $10^{16} \mathrm{~cm}^{-3}[50]$.

The analysis shows that electrically active defects produced by atomic displacement of $\mathrm{Si}$ by the irradiating electrons is on the order of the intrinsic defect density for a $1-\mathrm{MeV}$ electron fluence of $10^{16} \mathrm{~cm}^{-2}$. 
Fig. 4 shows that $1-\mathrm{MeV}$ irradiation at fluences between $10^{13}$ and $10^{14}$ $\mathrm{cm}^{-2}$ results in the degradation of a cell with an intrinsic layer thickness of $700 \mathrm{~nm}$. It appears that the onset of cell degradation occurs at fluences which are two to three orders of magnitude below the fluences predicted, assuming the defect generation mechanism is atomic displacement. This disagreement suggests that electron-induced atomic displacement of $\mathrm{H}$ or $\mathrm{Si}$ is not the main mechanism which reduces the relative efficiency of a-Si: $\mathrm{H}$ thin film solar cells when irradiated with $1-\mathrm{MeV}$ electrons of fluences less than about $10^{16} \mathrm{~cm}^{-2}$. Additionally, the fact that the defects anneal at temperatures of about $200^{\circ} \mathrm{C}$ also suggests that atomic displacement is not the dominant defect generation mechanism.

Defects produced by electronic excitation are more difficult to quantify than defects produced by atomic displacements because the cross section for the possible electronically-active defect generation reactions are not known. We can develop our insights into the effect of electronic excitation by considering two extreme cases, namely, the effects of electronic excitations in crystalline silicon and polymeric materials.

Crystalline silicon materials do not degrade as a result of energy deposited in the lattice by way of electronic excitation. Measurements show the range of $1 \mathrm{MeV}$ electrons in crystalline silicon is about $2.3 \mathrm{~mm}$ and the electronic stopping power is about $300 \mathrm{eV} / \mathrm{micron}$ [56]. Investigations show that, on the average, one electron-hole pair is produced for about every $3.6 \mathrm{eV}$ an electron losses by electronic excitation as it slows down [57]. The electron-hole, pair is produced by the excitation of a valence electron from a silicon-silicon bond into the conduction band. Upon collection of the electron and hole, the crystalline lattice is restored to its former defect free and electrically neutral state. It is this property of crystalline silicon, as well as its mono-elemental nature, which makes it a desirable material for use in the detection of $\mathrm{MeV}$ electrons and protons.

Polymeric materials, unlike crystalline silicon, are compound materials which degrade as a result of the electronic energy deposited by $\mathrm{MeV}$ particles. Bond reordering and breaking and chain scission occur. Irradiation produces major chemical and structural changes which are complex; the changes cannot be related in a simple way to bond strengths of the various molecular structures in the materials [58].

a-Si:H contains about ninety percent silicon and ten percent hydrogen. While the hydrogen in currently fabricated device-grade a-Si:H materials is bonded primarily as a $\mathrm{Si}$ monohydride (Si-H), materials fabricated several years ago contained large amounts of hydrogen bonded in $\mathrm{Si}$ dihydride $\left(\mathrm{Si}-\mathrm{H}_{2}\right)$ and $\mathrm{Si}$ polyhydride $\left(\left[\mathrm{Si}-\mathrm{H}_{2}\right]_{n}\right)$ complexes. Electronic stopping of $\mathrm{MeV}$ electrons leads to the excitation of the conduction electrons and the $\mathrm{Si}-\mathrm{Si}$ and $\mathrm{Si}-\mathrm{H}$ bonds. The electronic excitation may lead to breaking and/or reordering of the Si-Si and $\mathrm{Si}-\mathrm{H}$ bonds, and, in material containing polyhydrides, in bond reordering, chain scission and bond cleavage. The degradation 
mechanisms in high quality device a-Si:H caused by the electronic excitation should be limited to bond reordering and breaking of the $\mathrm{Si}-\mathrm{Si}$ and $\mathrm{Si}-\mathrm{H}$ bonds. It is expected that the excitation of the Si-Si bonds may lead to defects produced by bond reordering and breaking. The possible effects of the deposition of electronic energy in the $\mathrm{Si}-\mathrm{H}$ bonds also includes the production of defects by bond ordering and breaking. The difference between $\mathrm{Si}-\mathrm{Si}$ and $\mathrm{Si}-\mathrm{H}$ bond excitation is the atomic hydrogen may diffuse away from the excited zone, leaving the silicon atom to react with its neighbors in much the same manner as the excited Si-Si bonds; the hydrogen may react with other defects, bond with another hydrogen atom, or remain as an interstitial in the amorphous network. Most of the energy deposited in electronic excitation will be converted to phonons as the excited bonds return to the ground states and recombination of charge carriers occurs.

The microstructure of defects in a-Si:H have been the subject of several papers and their complete characterization is incomplete [59]. The fact that $\mathrm{MeV}$ electron-induced defects anneal at temperatures of about $200^{\circ} \mathrm{C}$ would appear to support electronic excitation, as compared to atomic displacements, as the major defect generation mechanism. The reasons for this suggestion are as follows:

1. The average energy deposited by an energetic electron, 300 $\mathrm{eV} /$ micron, will be deposited more uniformly on an atomic scale than the energy deposited in atomic displacements. The energy deposition mechanism, for the most part, involves energies of the order of a few $\mathrm{eV}$.

2. The energy deposited by electronic excitation can cause bond ordering and breaking. The activation energies for bond reordering should be less than one $\mathrm{eV}$ because the strengths of the $\mathrm{Si}-\mathrm{Si}$ and $\mathrm{Si}-\mathrm{H}$ bonds are about 2.4 and $3.4 \mathrm{eV}$, respectively [60].

3. Electronic excitation can break $\mathrm{Si}-\mathrm{H}$ bonds and produce interstitial hydrogen. Hydrogen diffusion activation energies may be as low as 0.15 $\mathrm{eV}$ in silicon, thereby suggesting that it readily diffuses through silicon at low temperatures [61]. The fact that hydrogen may diffuse at low temperatures in silicon suggests that it may also play a role in passivating electronically active defects during low temperature annealing.

It is clear that most of the explanations of the radiation resistance of a-Si:H devices and thin-film are highly speculative. There is clearly a need for detailed and systematic studies using state of the art device quality materials. The materials must be well characterized using several techniques. Since room temperature annealing occurs, experiments must be designed considering that the time between irradiation and analysis is critical in the elucidation of the basic mechanisms. Investigators also need to report the details of fabrication and the relevant dimensions of the films and devices studied. This is important if results from different laboratories are to be compared as well as to facilitate theoretical interpretations of the basic mechanisms. 


\section{CONCLUSIONS}

Recent advances in the technology of thin-film solar cells [62] have led to interest in the possibilities of using thin-film cells for lightweight solar arrays in space. Thin film solar cells are considerably more radiation tolerant than single-crystal solar cells. CuInSe ${ }_{2}$ cells shows no degradation when exposed to $1-\mathrm{MeV}$ electrons to fluences up to $2 \cdot 10^{16}$ $\mathrm{cm}^{-2}$. a-Si cells showed some degradation when exposed to $1-\mathrm{MeV}$ electrons at fluences over about $10^{15} \mathrm{~cm}^{-2}$. This degradation can be annealed out at temperatures as low as $175^{\circ} \mathrm{C}$. Both CuInSe $\mathrm{C}_{2}$ and a-Si showed good performance when exposed to $1-\mathrm{MeV}$ proton irradiation; $\mathrm{CuInSe}_{2}$ showed negligible degradation up to about $10^{11} 1-\mathrm{MeV}$ protons $/ \mathrm{cm}^{2}$, and a-Si up to about $10^{12} / \mathrm{cm}^{2}$. These results are comparable to or slightly better than InP solar cells, and fifty to a hundred times more resistant to degradation than single crystal Si or GaAs cells.

While a great deal of work has been done to characterize the effect of $\mathrm{MeV}$ electrons and protons on amorphous silicon, both solar cells and thin film materials, the fundamental mechanisms are not well understood. There are three main reasons for our failure to understand the radiation resistance of thin film solar cells. First, the influence of room-temperature annealing is not understood. Without a detailed understanding of room-temperature annealing, it is not possible to quantify the radiation-induced electrically active defect density. Second, technological developments have led to thin film cells with much better efficiencies, and therefore ralses the question of the role device quality plays in radiation resistance. Finally, the thin film materials technology has evolved rapidly and basic research has not been able to focus on the materials to probe fundamental issues, l.e., the "window of interest moves faster than the fruits of basic research."

\section{ACKNOWLEDGEMENTS}

One of the authors, JRW, wishes to acknowledge the assistance of J. Scott Payson, Salman Abdulaziz and Yang Li, of Wayne State University, in the preparation of the manuscript. Support of the National Aeronautics and Space Administration, Grant NAG 3-833, and the Institute of Manufacturing Research, Wayne State University, are appreciated.

Geoffrey Landis would like to acknowledge support by the National Research Council/NASA Lewis Resident Research Associateship program and by NASA Lewis under grant NAS33-25266. 


\section{REFERENCES}

1. G.A. Landis, S.G. Bailey, and D.J. Flood, Space Power Vol. 8, No. 1/2, 1989, pp. 31-50; also printed as NASA Tech. Memo. 102017 (1989).

2. J. J. Hanak, E. Chen, C. Fulton, A. Myatt and J.R. Woodyard, Proc. of the Space Photovoltaic Research and Technology Conference, NASA Conference Publication 2475, 1986, p. 99.

3. J.J. Hanak, L. Walter, D. Dobias and H. Flaisher, Proc. of the Space Photovoltaic Research and Technology Conference, NASA Conference Publication 3030, 1988, p. 162.

4. Y. Kishi, H. Inoue, K. Murata, H. Tanaka, S. Kouzuma, M. Morizane, Y. Fukuda, H. Nishiwaki, K. Nakano, A. Takeoka, M. Ohnishi and Y. Kuwano, Tech. Digest of the International Photovoltaic Science and Engineering Conference 5, Kyoto, Japan, 1990, p. 645.

5. W. Wallace, E. Sabinsky, B. Stafford and W. Luft, Proc. of the 19th IEEE Photovoltaic Specialists Conference, 1987, p. 593.

6. N. Nakatani, K. Suziki, H. Okaniwa, and S. Sobajima, Tech. Digest of the International Photovoltaic Science and Engineering Conference 4, 1989, Vol. 2, p. 639.

7. R.B. Hall, R.W. Birkmire, J.E. Phillips, and J.D. Meakin, Proc. of the 15th IEEE Photovoltaic Specialists Conference, 1981, p. 777.

8. R. Hill, and J. D. Meakin, in T. J. Coutts and J. D. Meakin (eds.), Current Topics in Photovoltaics, Vol. 1, Academic Press, Inc., 1985, p. 223.

9. A. L. Fahrenbruch and R. H. Bube, Fundamentals of Solar Cells, Academic Press, New York, 1983, p. 418.

10. A. M. Barnett, Proc. of the 2nd European Photovoltaic Solar Energy Conference, 1979 , p. 328.

11. L. L. Kazmerski and S. Wagner, in T. J. Coutts and J. D. Meakin (eds.), Current Topics in Photovoltaics, Vol. 1, Academic Press, Inc., 1985, p. 41.

12. K. Zweibel, H.S. Ullal, and R. Mitchell, Proc. of the 21 st IEEE Photovoltaic Specialists Conference, Vol. I, 1990, p. 459.

13. K. Mitchell, C. Eberspacher, J. Ermer and D. Pier, Proc. of the 20th IEEE Photovoltaic Specialists Conference, 1988, p. 1384.

14. W. S. Chen, J. M. Stewart, B. J. Stanbery, W. E. Devaney and R. A. Mickelsen, Proc. of the 19th IEEE Photovoltaic Specialists Conference, 1987, p. 1445.

15. V. Ramanathan, L. Russell, C. H. Liu, P. V. Meyers and H. S. Ullal, Proc. of the 20th IEEE Photovoltaic Specialists Conference, 1988, p. 1417.

16. P. V. Meyers, 7th European PV Conference.

17. C. F. Gay, R. R. Potter, D. P. Tanner and B. E. Anspaugh, Proc. of the 17th IEEE Photovoltaic Specialists Conference, 1984, p. 151.

18. C. E. Byvik, W. S. Slemp, B. T. Smith and A. M. Buonchristiani, Proc. of the 17th IEEE Photovoltaic Specialists Conference, 1984, p. 155.

19. S. Guha, J. Yang, A. Pawlikiewicz, T. Glatfelter, R. Ross and S. R. Ovshinsky, Proc. of the 20th IEEE Photovoltaic Specialists Conference, 1988, p. 79.

20. D. L. Staebler and C. R. Wronski, J. Appl. Phys., 51 (1980) 3262.

21. E. S. Sabinsky and J. L. Stone, Proc. of the 20th IEEE Photovoltaic Specialists Conference, 1988, p. 39. 
22. J. Yang, R. Ross, R. Mohr and J. P. Fourier, in D. Adler, Y. Hamakawa and A. Madan (eds.), Materials Issues in Amorphous-Semiconductor Technology, Materials Research Society Symposia Proceedings, Vol. 70,1986 , p. 475.

23. J.C. Schaefer, 3rd Photovoltaic Specialist's Conference, PIC-SOL 209/3, 1963, Vol. I, p. A2-1.

24. J.C. Schaefer and R. L. Statler, 4th Photovoltaic Specialist's Conference, PIC-SOL 209/5.1, 1964, Vol. II, p. A6-1.

25. H. W. Brandhorst, Jr. and R. E. Hart, 4th Photovoltaic Specialist's Conference, PIC-SOL 209/5, 1964, Vol. II, p. A7-1.

26. J. Bernard, J. Berry, J-P. Buisson, and A. Paillous, "Partial Results on CdS and CdTe Thin-film Solar Cells Spatial Reliability," Cellules Solaires, Gordon and Breach, July 1970, p. 229.

27. W.L.C. Hui, 5th Photovoltaic Specialists Conference, 1965, PIC-SOL 209/6.1 Vol. II, p. C5-1.

28. D.J. Curtin, 7th Photovoltaic Specialist's Conference, 1968, p. 206.

29. H. Dursch, W. Chen and D. Russel, Proc. of the Space Photovoltaic Research and Technology Conference, NASA Conference Publication 2408, 1985, p. 165.

30. M. Katayama, H. Morimoto and K. Sugawara, Phys. Stat. Sol. (A) 78 (1983) K5.

31. R. Street, D. Biegelsen and J. Stuke, Phil. Mag. 40B (1979) 451.

32. U. Schneider and B. Schröder, Proc. of the 21th IEEE Photovoltaic Specialists Conference, 1990, p. 1521.

33. R. Schwarz, J. Kolodzey, S. Aljishi. S. Wagner and R.T. Kouzes, Proc. of the 18th IEEE Photovoltaic Specialists Conference, 1985, p. 903.

34. J. J. Hanak, A. Myatt, P. Nath and J. R. Woodyard, Proc. of the 18th IEEE Photovoltaic Specialists Conference, 1985, p. 1718. This paper erroneously listed the tandem junction cells as dual gap cells with an a-Si,Ge:H,F bottom cell. The cells were a-Si:H,F single bandgap cells. See [35].

35. J. J. Hanak, C. Fulton, A. Myatt, P. Nath and J. R. Woodyard, Proc. of the 21 st Intersociety Energy Conversion Engineering Conference, Vol. 3, 1986, p. 1436.

36. B. E. Anspaugh and R. G. Downing, Proc. of the 17th IEEE Photovoltaic Specialists Conference, 1984, p. 23.

37. I. Weinberg, C. K. Swartz and R. E. Hart, Jr., Proc. of the 20th IEEE Photovoltaic Specialists Conference, 1988, p. 893.

38. S. Abdulaziz, J.S. Payson, Y. Li, and J.R. Woodyard, Proc. of the 21 st IEEE Photovoltaic Specialists Conference, Vol. II, 1990, p. 1510.

39. J. G. Severns, R. M. Hobbs, N. P. Elliot, R. H. Towsley, R. W. Conway and G. F. Virshup, Proc. of the 20th IEEE Photovoltaic Specialists Conference, 1988, p. 801.

40. W. E Horne, S. Cannaday, M. A. Thompson, P. Brothers and M. Morgan, Proc. of the 20th IEEE Photovoltaic Specialists Conference, 1988 , p. 831.

41. D. Engemann, R. Fischer, F. W. Richter and H. Wagner, in B. T. Kolomiets (ed.), Proc. of the Sixth Conference on Amorphous and Liquid Semiconductors, 1975, p. 217.

42. U. Voget-Grote, J. Stoke and H. Wagner, in G. Lucovsky and F.L. Galeener, eds., Structure and Excitations of Amorphous Solids, AIP Conference Proc., 31, 1976, p. 91. 
43. J.S. Payson and J.R. Woodyard, Proc. of the 20th IEEE Photovoltaic Specialists Conference, 1988, p. 990.

44. H. Schade, Semiconconductors and Semimetals, 21B (1984) 359. See also H. Schade and J.I. Pankove, J. De Physique, supplément au no. 10, Tome 42, (1981) p. C4-327.

45. U. Schneider and B. Schröder, in H. Fritzsche, ed., Amorphous Silicon and Related Materials, Advances in Disordered Semiconductors Vol. 1, (1988) p. 687.

46. U. Schneider, B. Schröder and F. Finger, J. Non-Crystalline Solids 114 (1989) 633.

47. J.R. Woodyard and J. J. Hanak, in D. Adler, A. Madan, Y. Hamakawa and M. Thompson (eds.), Amorphous Silicon Semiconductors - Pure and Hydrogenated, Materials Research Society Symposia Proceedings, Vol. 95, 1987, p. 53.

48. J.J. Hanak, E. Chen, A. Myatt, and J.R. Woodyard, Proc. of the 19th IEEE Photovoltaic Specialists Conference, 1987, p. 630.

49. G.W. Kinchin and R.S. Pease, Report Prog. Phys. 18, 1 (1955).

50. W.B. Jackson and N.M. Amer, Phys Rev. 25B, 5559 (1982).

51. J. F. Gibbons, W.S. Johnson and S.W. Mylrole, Projected Range Statistics: Semiconductors and Related Materials (John Wiley and Sons, Inc., New York, Second Edition, 1975).

52. J. S. Payson, S. Abdulaziz, Y. Li and J. R. Woodyard, Proc. of the Space Photovoltaic Research and Technology Conference, NASA Conference Publication (in press), 1989.

53. J. S. Payson, Y. Li and J. R. Woodyard, in A. Madan, M. J. Thompson, P. C. Taylor, Y. Hamakawa and P. G. LeComber (eds.), Amorphous Silicon Technology, Materials Research Society Symposia Proceedings, Vol. 149, 1989, p. 321.

54. A. Madan and M.P. Shaw, The Physics and Applications of Amorphous Semiconductors, Academic Press, New York, 1988, pp. 95 and 96.

55. J.W. Corbett, Solid State Physics, Supplement 7, Electron Radiation Damage in Semiconductors and Metals, Academic Press, New York, 1966, p. 20.

56. H.Y. Tada, J.R. Carter, B.E Anspaugh and R.G. Downing, Solar Cell Handbook, JPL Publication 82-69, 1982, pp. 3 through 38.

57. G.F. Knoll, Radiation Detection Measurement, John Wiley \& Sons, New York, 1979, p. 363.

58. D.R. Coulter, A. Gupta, M.V. Smith and R. E. Fornes, JPL Publication 85-101, 1986, pp. 9 and 10.

59. S. T. Pantelides, Phys. Rev. Lett. 57, 1986, p. 2979.

60. D. Adler in F. Yonezawa (ed.), Fundamental Physics of Amorphous Semiconductors, Solid-State Sciences 25, Springer-Verlag, New York, 1981, p. 14.

61. K. J. Chang and D. J. Chadi, Phys. Rev. 62, 1989, p. 937.

62. J.L. Stone, Tech. Digest of the International PV Science and Engineering Conference 5, Kyoto, Japan, 1990, p. 227. 


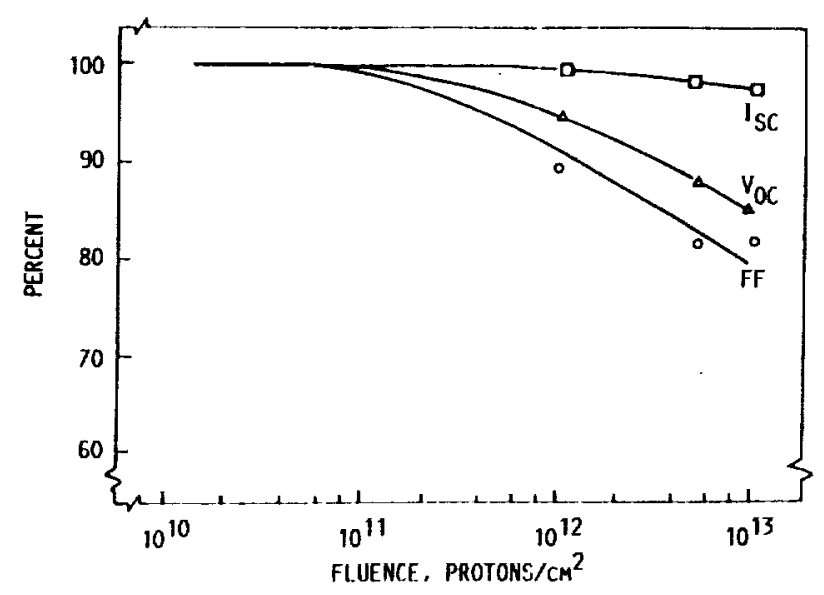

FIGURE 1. - EFFECT OF 1 MEV PROTON IRRADIATION ON THE OPEN CIRCUIT VOLTAGE. FILL FACTOR, AND SHORT CIRCUIT CURRENT OF CUINSE 2 SOL AR CELLS.

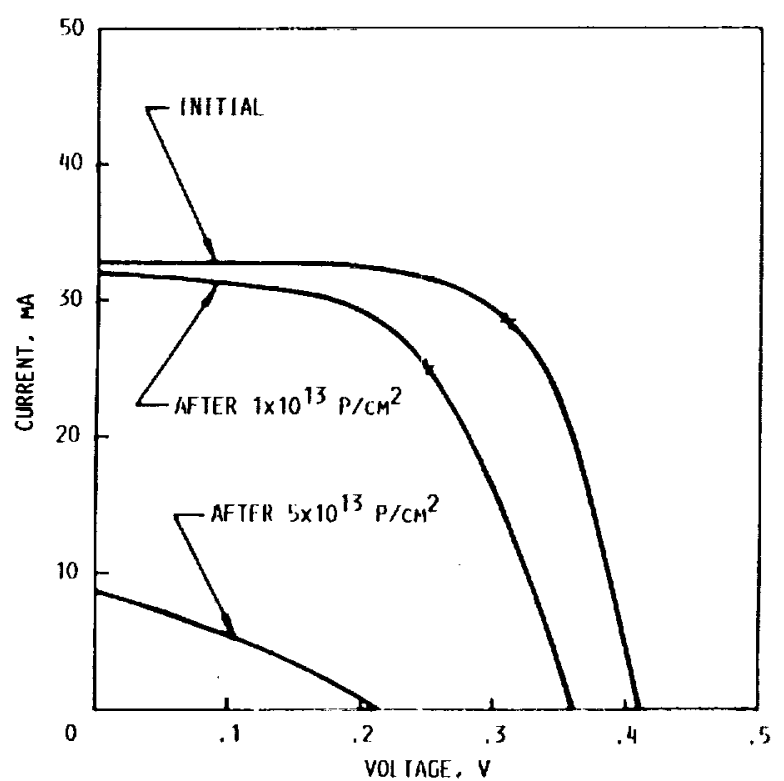

IIGISRT 2. - IV CINVE OF $A$ CUINSE 2 SOI AR CEII BF FORT AND N IIR I HEV PROION IRRADIAIION.

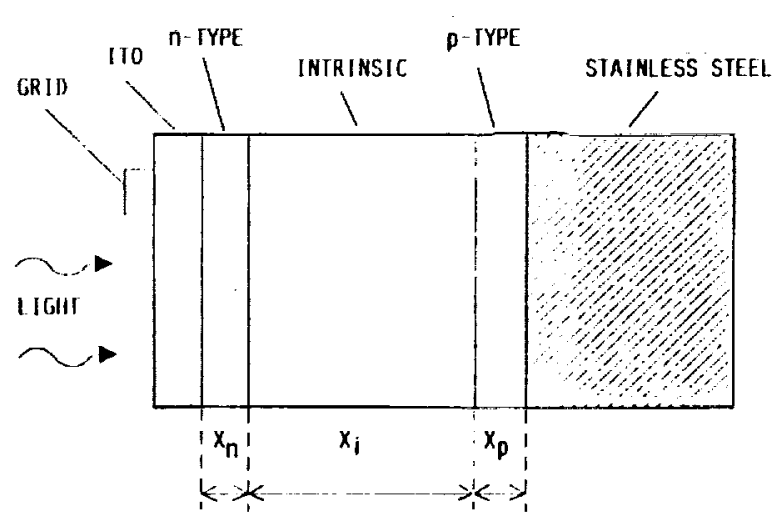

FICURE 3. - CROSS-SECTIONAL VIEW OF AN a-Si :II SOLAR CELI 1301.

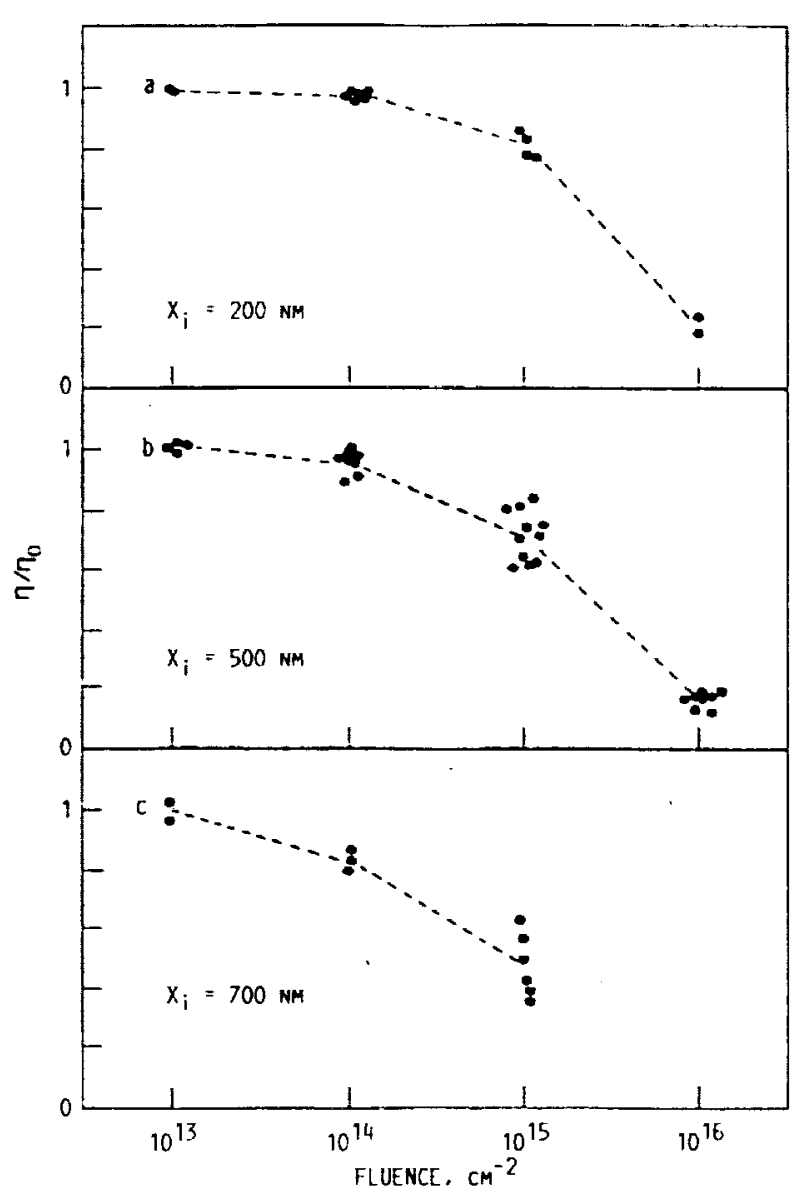

FIGURE 4. - SOLAR CELL RELATIVE EFFICIENCY VERSUS I MEV ELECTRON FLUENCE OF a-Si:H,F SOLAR CELLS WITH (a) $x_{i}=$ $200 \mathrm{NM}$ : (b) $x_{i}=500 \mathrm{MN}$ AND (c) $x_{i}=700 \mathrm{NM}[30]$.

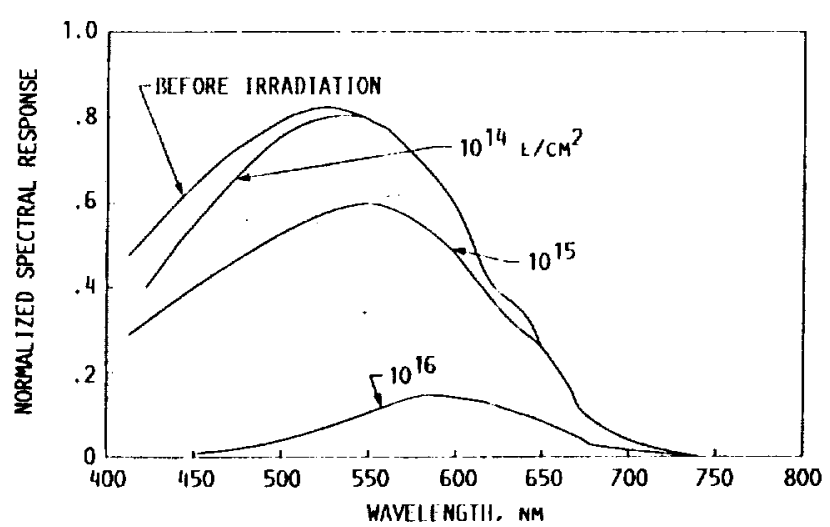

FIGURE 5. - OUANIUH EITICIENCY OF a-Si:H,F SOLAR CEILS WITH $x_{i}=500$ NM BETORE AND AFTER 1.00 MEV ELECIRON IRRADIATION [301. 


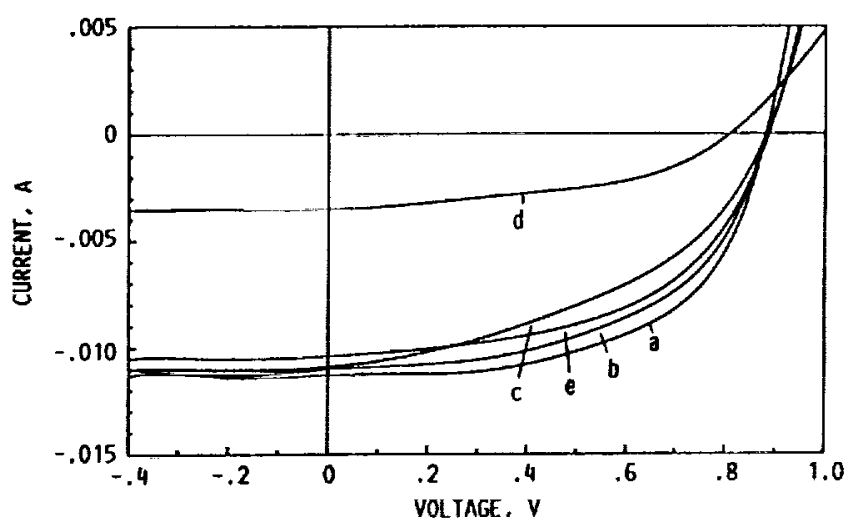

FIGURE 6. - TYPICAL CURRENT-VOL TAGE RESPONSE OF a-Si :H SOLAR CELLS BEFORE AND AFTER 1.00 MEV ELECTRON IRRADIATION. CURVE (a) IS THE RESPONSE OF A CELL WHICH HAS NOT BEEN IRRADIATED; (b) IS A CELL IRRADIATED TO A FLUENCE OF $10^{14} \mathrm{~cm}^{-2}$. (c) $10^{15} \mathrm{~cm}^{-2}$, (d) $10^{15} \mathrm{~cm}^{-2}$ AND (e) AMHEALED AT $200^{\circ} \mathrm{C}$ FOR THO HOURS $[181$.

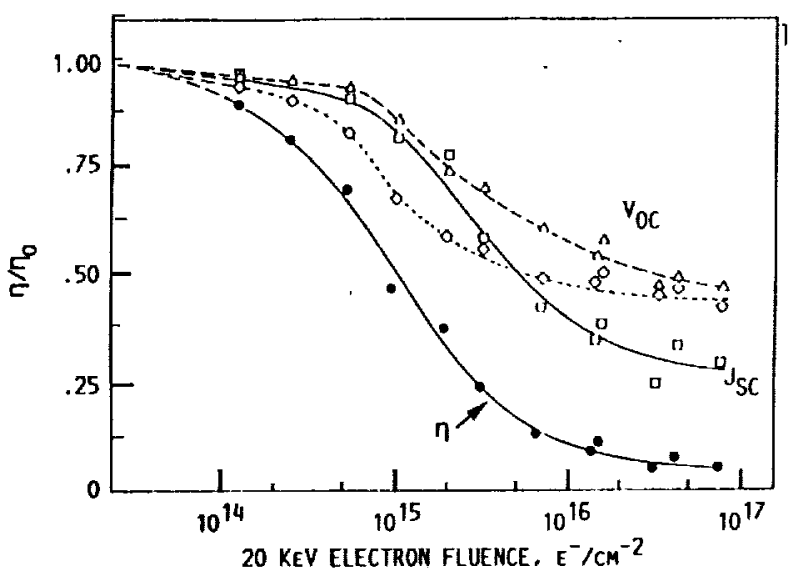

FIGURE 7. - EFFECT OF $20 \mathrm{KEV}$ ELECIRON IRRADIATION OH THE EFFICIENCY, SHORT CIRCUIT CURRENT AND OPEN CIRCUIT VOLTAGE OF a-SI ALLOY CELLS.

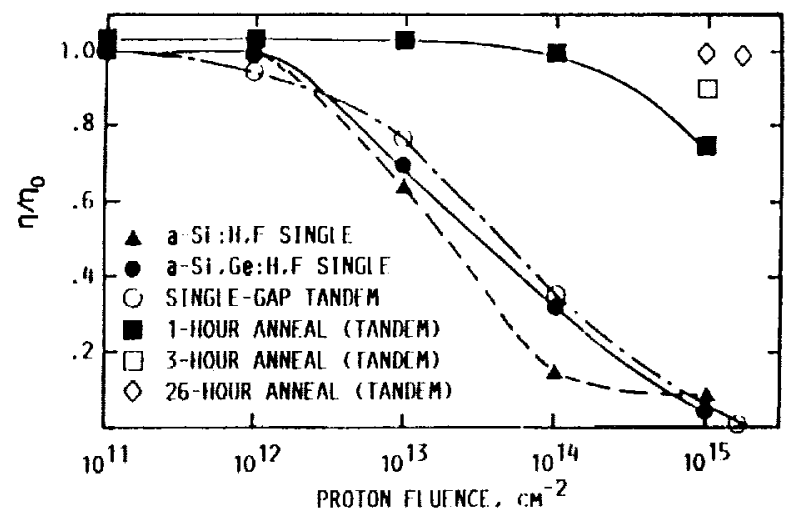

TIGURE 8, RIIATIVT CONVERSION EFTICIENCIES FOP VARIOUS a-SI :H SOLAR CELLS IRRADIATED WIFII I MEV PROTONS. FOL LOWING IRRADIATIION TIS TANDEM CELL WAS ANREALED AT $160^{\circ} \mathrm{C}$ FOR THE TIMES SHIOWN 1341.

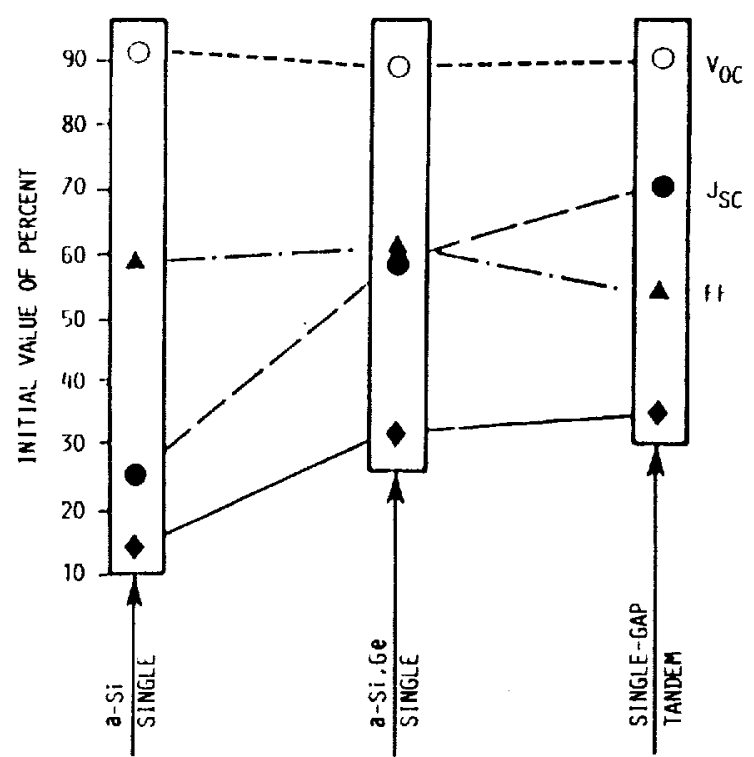

FIGURE 9. - CHANGE OF IIIE OPIN-CIRCUIT VOL IAGE. SHORT-CIRCUII CURRENT, FUII - FACIOR ANII CONVRSIOI. EFFICIENCY FOR YARIOUS a-Si :II SOLAR CEIIIS IRRADIAIED WITH A FIUFNCE OF $10^{14} \mathrm{~cm}^{-2}$ 1 MeV PROTONS 134 ).

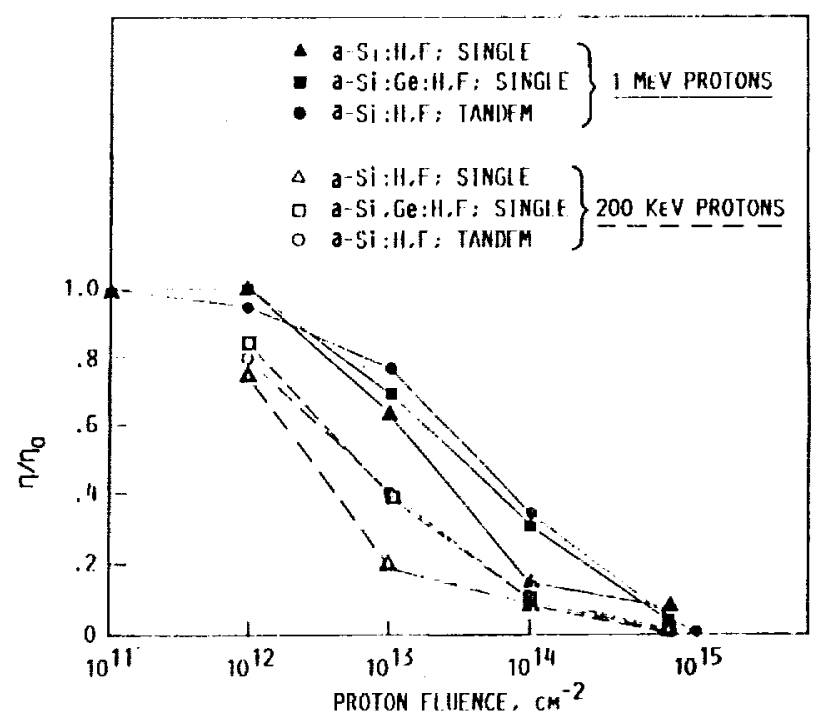

FIGURF 10. - EFFECT OF $200 \mathrm{KEV}$ AND 1.00 MEV PROTON IRRADI AIION ON THE REIATIVT CONYERSION EFTICIENCY OF SINGIEGAP TANDIM a-Si:II,F, AND SINGIE-IAP a-Si:HIF AND a-Si, Ge:ll.r CCIIS [351. 


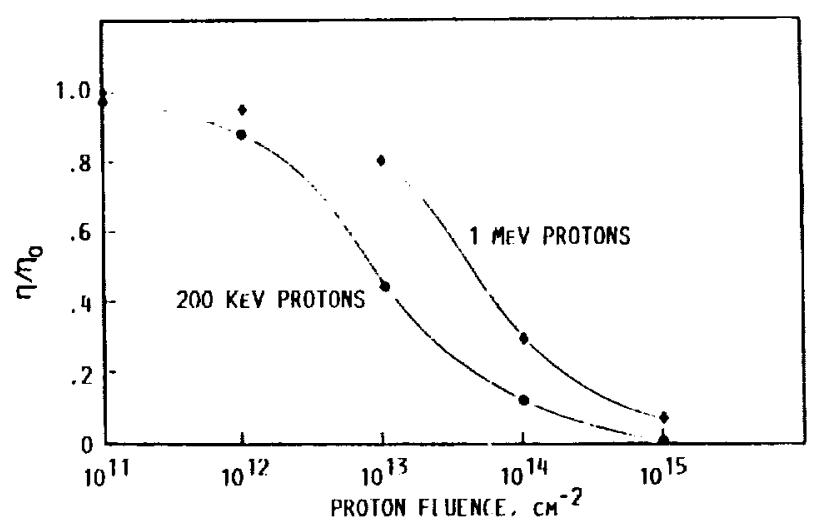

F IGURT 11. - FITECT OF $200 \mathrm{KEV}$ ANI) $1.00 \mathrm{MEV}$ PROTON IRRADIATION ON THE REIAIIVE CONVIRSION EFFICIFNCY OF TANDCM IUIAL - GAP CFILS FABRICAIED FROM a-SI:II,F AND a-Si,G :H,F AlIOYS 121 .

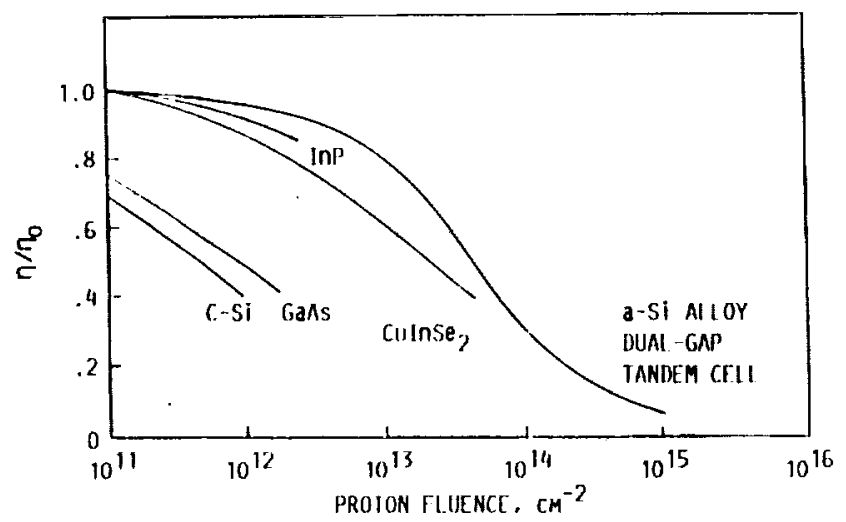

HIGIIRE $1 \%$. COMPARISON OF IHE EIFECT OF I MEV PROTON IRRADIAIION ON THE RLI ATIVE CONVERSION EFFICIENCY OF CRYSIALLINE Si. GaAs, CUInSE 2 AND DUAL-GAP TANDEM a-Si:H,F AND a-S ,G :Il,F CEIIS 12.34 .291 , THE InP DNIA ARE FOR 10 MEV PROTON IRRMDIATION I37].

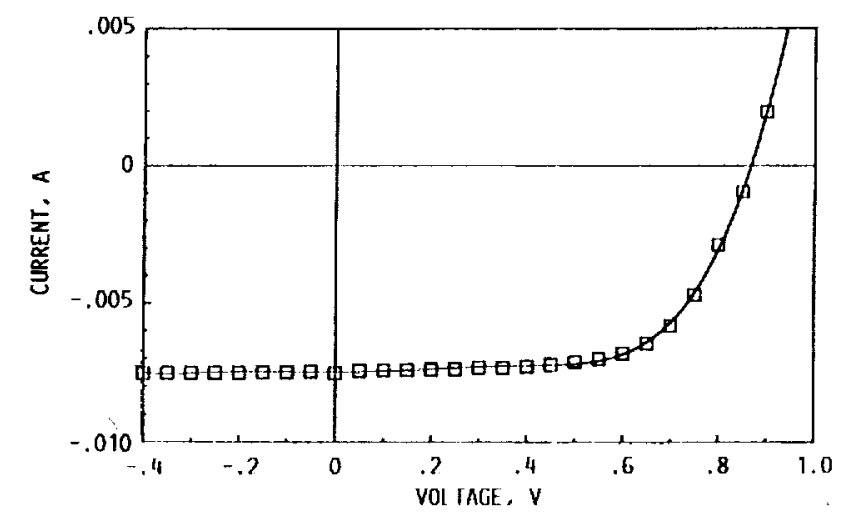

I IGIJRE 13. - CIIRRENT-VOI TACF CHARACITRISTICS OF NN IRRADIATED SINGLE JUNCTION a-3i:II SOIAR CFIL.

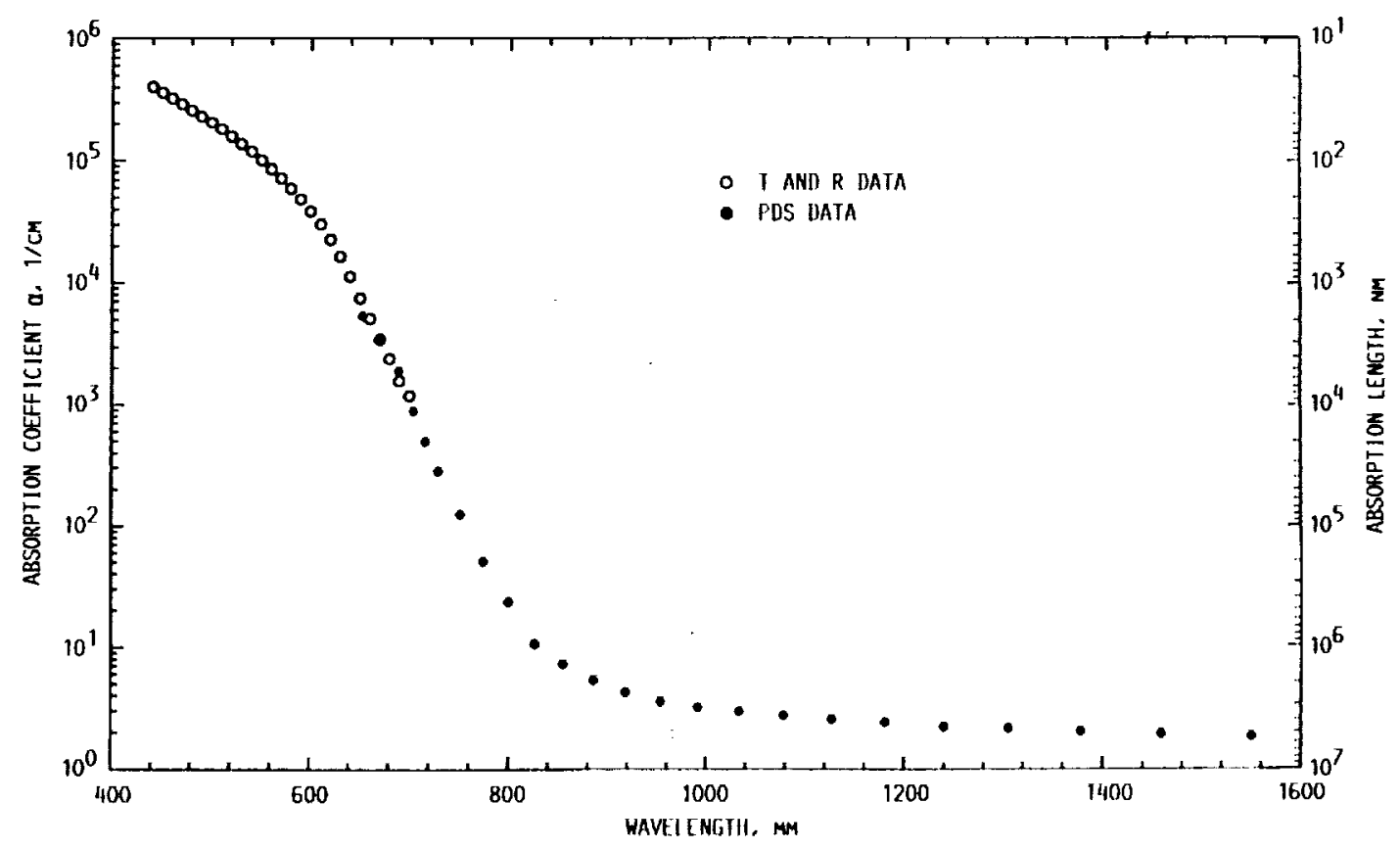

FIGIIRE 14. - OPTICAL AISSORPTION COEFFICIENT VERSUS WIVIIENGIH FOR a-SI:II MEASUREU ON A 1.0 MICRON THICK FII.M. THE OPEN CIRCIES ARE DATA HEASURED US:MG TIE IRANSMISSION AND RETIECTION METHOD AND THE SOLID CIRCLES MEASURED USING, PHOTOTIERMAI DEFIICTION SPECTROSCOPY. 


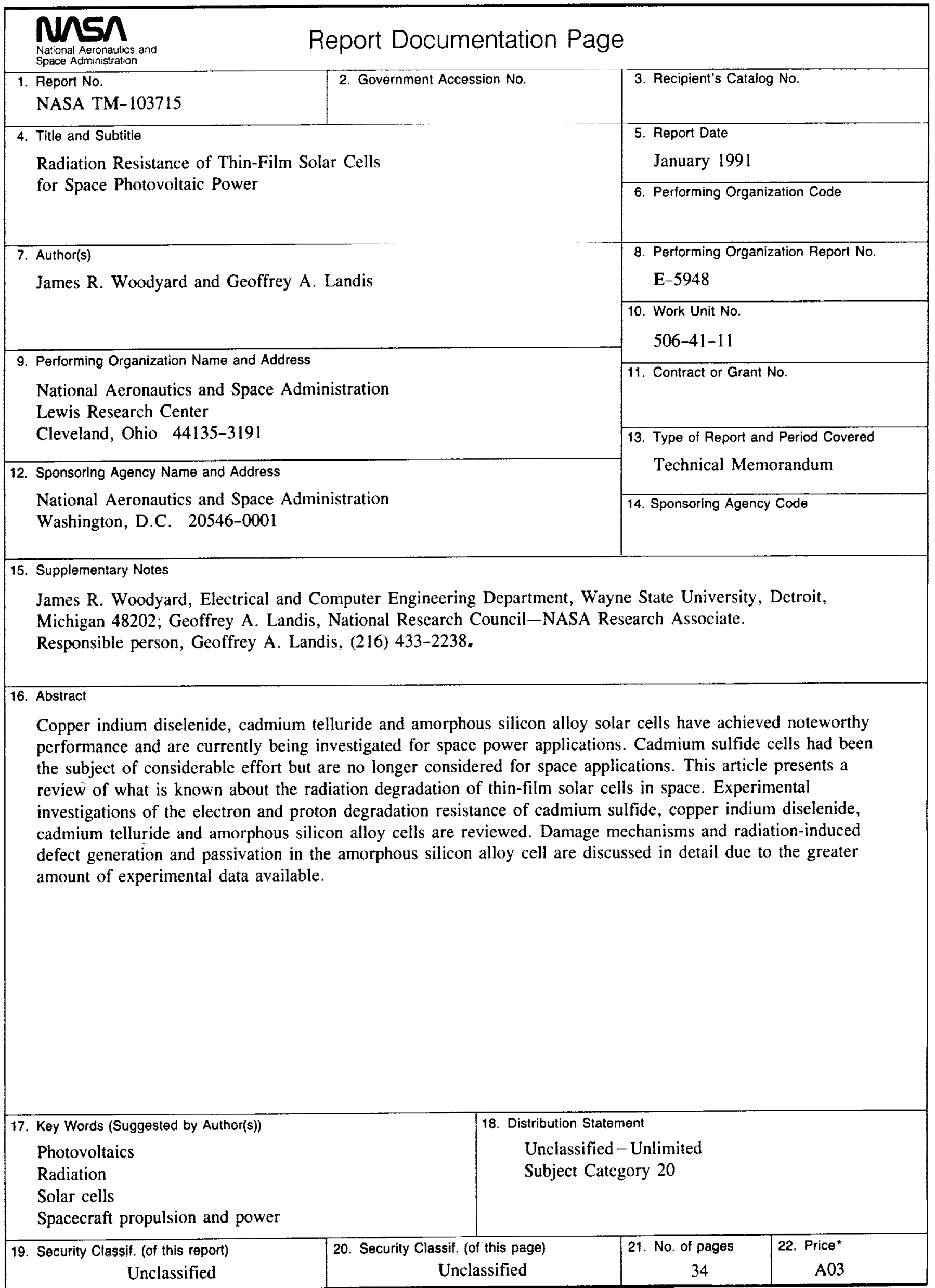

